\title{
A Conceptual History of 'Chue-Yuk-In': Critical Interpretation of Its Cultural Meanings as the Ideal Type of the National Sporting Citizen (1945-1961)
}

\author{
Jae Chul Seo ${ }^{1}$ and Hyunwoo Jung ${ }^{2 *}$ \\ ${ }^{1}$ Department of Marine Sport, Pukyong National University, Busan, Korea \\ ${ }^{2}$ Department of Policy and R\&D, Korea Institute of Sport Science, Seoul, Korea
}

\begin{abstract}
[Purpose] The purpose of this study was to explore cultural meanings of the concept of 'Che-Yuk-In' through a critical examination of how it was described, portrayed, and represented in the narratives of the mainstream newspapers in the early days of the nation(1945-1961). [Methods] As for the data collection and method, a total of 338 articles were collected by searching of "Che-Yuk-In" through the database provided by the Naver News Library. Sorting out them with the point of whether the concept simply denotes the number of players or the majority of athletes, for example, we select 140 column-type articles and analyzed how it serves as a linguistic element and what discourses were involved in the narratives. [Results] Our argument is twofold: 1) the concept of 'Che-Yuk-In' is a kind of self-representative terminology with which a particular group of people, who call themselves 'Che-Yuk-In', construct their collective identity into a particular type of the idealized subject, so-called sporting citizen, and 2) this construction consists of two functions: one is to share the emotion of pride by celebrating success and achievements of the sporting figures, and the other is to collectively reflect shame by criticizing negative incidents and controversies such as corruption, factional disputes, violent behaviors, which broke in the sporting practices. [Conclusions] With a brief summary, this paper concludes with some suggestions for future studies, in terms of how the shameful past should be embraced within the field of Korean sport history, and why a conceptual history of the 'Che-Yuk-In' might need to be further expanded.
\end{abstract}

Key words: concept, conceptual history, Che-Yuk-In, politics of pride \& shame, innocence.

\section{1)서 론}

이 연구는 ‘체육인'이라는 개념 혹은 단어가 한국 사회와 스포츠 실제 속에서 출현, 형성, 변화해 온 사회·문화적 의미 의 역사성에 주목하고, 그것이 언어 및 담론의 지형 속에서 사용, 이해, 소통되어온 특정한 성격의 유의미성을 '개념사

논문 투고일 : 2021.02.02.

논문 수정일 : 2021.03.23.

게재 확정일 : 2021.04.12.

* 교신저자 : 정현우(hjung@kspo.or.kr)
(概念史, conceptual history)'라는 역사연구의 한 접근을 통해 탐구하는 조그만 작업이다. 구체적으로, '체육인'의 기 표가 한국 사회 속에서 처음 등장하여 사회적 대표성을 형성 해나갔던 해방 정국과 건국 초기에 주목하고, 당시의 시대적 상황과 배경 속에서, 그것의 의미가 어떻게 매개되고 소통되 었는지, 누가 그리고 왜 그러한 의미(상징)생산에 관여한 것 인지, 나아가 그러한 의미 형성의 역동성은 오늘을 사는 우 리에게 어떠한 함의와 시사점을 제공할 수 있는지 등을 논의 하는 것이다.

강조하건대, 이 연구의 목적은 ‘체육인’이 과연 누구인지 
그리고 그것이 정확하게 어떤 주체와 대상을 지칭하는지를 규명하는 것이 아니다. 다음 장에서 논의하겠지만, 우선, '체 육인'이라는 개념/단어의 의미를 법·제도·정책적 차원에서 ‘정의'하여 ‘합의'하는 일은 무엇보다 중요하고 또 시급한 일 이라는 점을 밝힐 필요가 있겠다. 그래서 아마도, 그러한 시 도와 작업으로 '확립' 가능한 체육인의 '의미'가 존재하거나 혹은 존재할 수 있다면, 그것은 ‘체육인’이라는 개념/단어의 법적, 제도적, 혹은 정책적 '의미’로 표현할 수 있을 것이다.

그러나 그러한 성격의 작업과는 달리, 우리의 연구는 '체 육인'이라는 개념/단어1)의 역사적이고 문화적인 의미를 탐 구하는 것이다. 구체적으로, 필자들이 취하고 있는 '개념史' 적 접근은 (특정한) 개념 그 자체의 역사를 밝히고 규정하기 보다는, (특정한) 개념이 사용되는 '맥락'을 검토하여 해석하 는데 방점을 찍는 학술적 작업이다. 따라서, 우리가 천착하 는 것은 '체육인'의 개념/단어를 누가 언제, 누구와의 관계 속에서, 어떻게, 그리고 왜 사용해왔는가의 질문이다.2) 다시 말해, '체육인' 의 개념/단어가 사용되고 소통되어 온 역사적 흐름 속에는, 그것을 말하고 듣고 이야기하며 소통해 온 사 람들이 서로 관계하고 상호작용하면서 만들고 구성(형성)하 는 정치적이고 사회적이며 문화적인 의미도 '함께' 있으며, 그것을 공감해보는 것 또한 의미 있고 가치 있다는 것이다.

특히, 필자들은 ‘체육인'의 개념/단어가 본격적으로 등장 하여 일종의 사회적 대표성을 얻게 되는 시기로 광복 이후부 터 제3공화국이 출범하기 이전까지의 시기(1945-1961)에 주목하였다. 그리고 본 연구의 제목이 시사하듯, 우리는 그 러한 시대적 조건과 배경 속에서 '체육인'의 개념이 사용되 고 소통되며 영향력을 발휘하게 된 언어적 현상의 유의미성 을 이른바 ‘체육인'의 개념이 '탄생'한 국면으로 틀 지어 개 념화하였다. 개념史를 창안하여 확산시킨 선도적 학자 Reinhart Koselleck이 주장하였듯이, 모든 개념은 특정한

1) 필자들은 이 연구의 주제어인 '체육인'을 개념사적 접근을 따 라 '단어'와 구별된 것으로서의 '개념'으로 인식한다. 그러한 이유와 배경에 대해서는 2장에서 논의하였는데, 해당 부분에 다가가는 동안, 일단 '체육인'의 용어를 '개념' 혹은 '단어'를 포괄적으로 지시하는 차원에서 '개념/단어'로 표기한다.

2) 우리가 일상적으로 듣고 말하면서 사용하는 어휘 중에는, 그것 이 정확하게 무엇을 의미하는지 명확하게 설명할 수는 없지 만, 그것을 사용하고 활용하는 상황과 맥락을 통해서 그 쓰임 새를 잘 이해하고 있는 개념/단어들이 많다. '체육인'의 개념/ 단어 역시 정의하기 어려운 점이 있지만, 그것이 사용되는 '맥 락'에 초점을 두고 해석해본다면, 그것 역시 '체육인'의 의미 를 잘 이해하게 되는 또 하나의 방식이 될 수 있을 것이다.
사회적 집단들의 정치적, 사회적 관점과 입장 및 함의에 따 라 만들어지는 것이며, 또한 그들이 처한 "현실을 통합시기 고 각인시키며 폭발시키는 힘”을 가지고 있다(Na, 2015). 그렇다면, 해방공간과 건국 초기의 시대적 조건과 사회적 배 경 속에서, '체육인'의 개념/단어가 등장, 소통, 사용하게 된 국면 속에는 어떠한 사회적 집단들의 관점, 입장, 함의 등이 관계되어있는 것일까? 또한, '체육인'의 개념/단어는 '체육 인'이라는 이름을 집합적으로 공유한 주체들에게 어떠한 “현 실을 어떻게 통합시키고 각인시키며 폭발시키는 힘”으로 작 용하며 존재했을까?

필자들의 주장은 크게 세 가지다. 첫째, '체육인'의 개념 이 본격적으로 출현, 사용, 소통하게 된 '맥락' 으로, 해방공 간과 건국 초기 이른바 새로운 민족적-국가적 주체로서 '국 민'을 호명하기 시작한 ‘주체화 담론' 의 지형에 주목할 필요 가 있다. 당시의 한국 사회는 국가건설의 주체로서 '국민'이 라는 새로운 주체를 다양한 영역과 분야에서 호명하고 있었 는데, '체육인'의 개념은 그러한 민족적-국가적 주체의 호명 이 ‘체육'이라는 문화적 실제 속에서 매개되어 구성, 형성된 '체육적' 표상이다.

둘째, '체육인'의 개념은 집합적 정체성의 형성에 관여하 는 언어적 기능을 수행한다. '민족/국민'에 대한 호명은 곧그 들에게 정체성을 부여하면서 주체를 구성해내는 과정이듯이, '체육인' 으로 호명하는 것 역시 특정한 집단적 주체들의 정체 성을 특정한 내용과 방식으로 구성하고 형성하는 자기-재현 의 언어이다. 구체적으로, 그러한 '체육인' 개념의 사용 속으 로 유입되는 지배적 의미는 주로 '체육' 혹은 '스포츠'야말로 세계와 공정하게 경쟁하여 승리함으로써 한국을 알릴 수 있 게 되는 문화의 효자라거나, 또는 '체육인'(들)이야말로 건강 한 신체와 건전한 정신의 소유자를 상징하는 순수하고 비정 치적이며 강직한 사람들이라는 자기-정의의 메시지이다.

셋째, 이러한 ‘체육인'의 지배적 의미/이데올로기는 두 가 지 감정이 대조되는 서사적 패턴을 통해 강화된다. 한편으 로, '체육인' 의 개념은 체육 관련 개인, 집단 및 조직의 성과 나 업적을 치하하고 확인하는 서사 속에 등장하면서, '자부 심과 긍지(pride)'의 감정을 공유하는 과정을 통해 '체육인' 의 집합적 정체성을 긍정적으로 강화한다. 다른 한편으로, ‘체육인'의 개념은 비도덕적이며 불미스러운 사건과 행태들 을 지적하고 비판하는 서사 속에 등장하면서, '수치와 부끄 러움(shame)' 의 감정을 반성하고 성찰하는 교감을 통해 다 시금 ‘체육인’의 (긍정적) 정체성을 회복하거나 재강화한다. 
이상의 주장을 구체화하는 이하의 본론은 크게 다섯 부분 으로 구성되어 있다. 먼저, 개념史란 것이 무엇이며, 왜 ‘체육 인'의 개념을 개념史의 접근과 관점에서 분석, 해석할 필요가 있는지에 대한 문제의식을 피력하였다. 이어서, '체육인'의 개념을 해석하는 틀과 방법으로, 왜 민족-국가적 주체를 호 명하는 담론에 주목하는지를 설명하고, 아울러 이 연구가 개

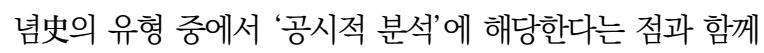
연구의 시기와 대상 자료의 선정 및 수집 방법 등에 대해서도 간략히 언급하였다. 다음으로, ‘체육인’의 개념이 등장하는 신문 기사의 내러티브를 두 가지 유형으로 구분하여 정리하 였는데, 하나는, 긍정적인 담론으로, '자부심/긍지' 의 감정을 집합적으로 공유하는 양상의 내용과 성격이며, 다른 하나는, '수치/부끄러움'을 통한 성찰을 통해 정체성을 회복하고 재 확인하는 양상의 내용과 성격을 정리하였다. 끝으로, 결론에 서는 연구 전반에 대한 요약과 함께 몇 가지 제언을 담았다.

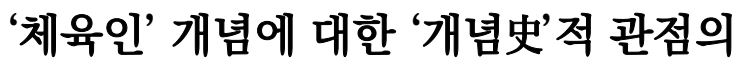 '해석'적 접근과 문제의식}

이 장에서는, ‘체육인'이라는 어휘/용어를 '개념' 으로 인

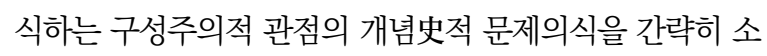
개하고, 그러한 해석적 접근이 개념/단어를 '정의'하는 작업 과 구별된다는 점을 설명한 다음, 왜 '체육인'의 개념을 ‘정 의'가 아니라 '해석'할 필요가 있는지, 그리고 이러한 작업 은 어떻게 의미 있고 또 가치 있는 것인지를 서술한다.

\section{‘사회적 구성물' 및 ‘해석'의 대상으로서의 '개념'}

이 연구는 ‘체육인’이라는 개념/단어를 사회·언어적 구성 물로 인식하고 그것을 역사적 해석의 대상으로 삼는다. 이러 한 문제의식은 '개념사(概念史, conceptual history)'라는 학문적 이름으로 형성되어 있는 '역사하기(doing a history)'의 한 방식(historiography)에서 영감을 얻은 것 이다. 요컨대, 개념史 연구는 '개념'이라는 렌즈를 통해 역사 속의 사람들과 세상을 이해해보는 것을 지향한다. 사람들이 주고받으며 소통하는 어휘, 단어, 개념 그 자체의 의미를 파 악하는 것에 집중하기보다는, 한 개념을 통해 누가 무슨 이 야기를 어떻게 주고받으며 소통했는지를 살펴보는 것이다. 즉 '개념' 의 문화적 사용에 관심을 두고, 그것의 언어적 의미
와 효과 그리고 사회적 영향력 등을 읽어내는 것이다.

이러한 개념史 연구의 해석적 접근에는 '개념' 을 일종의 '사회적 구성물(social construct)'로 인식하는 관점이 깔 려있다. '개념'이라는 것은 시간과 공간을 초월하여 항상 고 정적으로 존재하는 특정한 객관적 실체가 아니라, Koselleck 이 주장하였듯이, "역사적 변화과정 속에서 부단히 의미[의] 변화를 겪는 유연하고 유동적인 언어적[·사회적] 구성물”이 라는 것이 개념사학자들의 개념관(觀)이다( $\mathrm{Na}, 2010 \mathrm{a})$. 특 정한 시대적 조건과 배경 그리고 특정한 사회·문화적 맥락 과 국면 아래, 특정한 사람들이 서로 관계하고 매개하는 특 정한 상호작용의 과정을 통해 만들어지고 구성, 형성된 언 어적 산물이 곧 '개념'이라는 것이다.

중요한 것은, '개념'에 대한 구성(주의)적 관점의 해석적 탐구가 그것을 '정의' 하는 지적 작업과 구별된다는 점이다. 사회적 구성물로서의 '개념' 은 해석해야 할 대상인 것이지 '정의'할 수 있는 대상이 아니라는 것이 핵심이다. 어휘/단 어/개념 등이 지시하는 외연의 경계를 구분하는 '정의'와 달 리, 그것이 내포하고 함의하는 의미와 상징의 맥락적이고 관계적인 역동성을 이해하고 읽어내는 것이 곧 해석이다. 이러한 '정의'와 '해석'의 구별에 대해, 개념사학자들은 Friedrich Nietzsche가 『도덕의 계보학』에서 언급한 내용 을 자주 인용하여 설명하곤 하는데, 그것은 오직 비역사적 인 개념들만이 ‘정의'될 수 있으며, 역사성을 가진 개념은 '정의'가 아니라 ‘해석'이 필요하다는 역사적 통찰이다( $\mathrm{Na}$, 2003; Kim, 2009).

이러한 ‘정의'와 ‘해석' 의 구별을 통해, 개념史 연구는 '단 어'를 해석의 대상에 포함하지 않는다. 간단히 말해, '개념' 을 '단어'와 구별하는 가장 큰 차이점은 그것의 “다의성'에 있다. Koselleck의 개념史를 연구하여 소개한 $\mathrm{Na}(2010 \mathrm{a})$ 가 인용하여 표현하였듯이, "단어는 사용되면서 명확해질 수 있[지만], 개념은 개념이 되기 위하여 다의적이어야 한 다." 일반적으로 "단어'는 대상을 지시하는 말이고, 개념은 그 대상을 추상화한 말이다. 물론 하나의 단어도 여러 의미 를 전달하고 담아낼 때가 있다. 그러나 단어는 사용하면서 의미가 명확해지는 반면, 개념은 "정치적, 사회적인 의미 연 관들로 꽉 차 있어서 사용하면서도 계속해서 다의적으로 머 무르는 단어”라는 것이다(Kim. 2015). 즉 다의성의 요소를 가지고 있는 단어를 개념으로 이해할 수는 있지만, 그렇다 고 해서 모든 단어가 개념이 되는 것은 아니다.

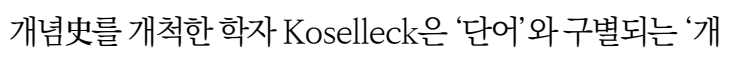


념'의 해석적 지위와 위상을 '기본 개념'이라는 용어로 설명 하였는데, $\mathrm{Na}(2010 \mathrm{a})$ 는 그것을 다음과 같이 설명하고 있다.

기본 개념이란 한 단어 속으로 이것이 지칭하는 수많은 정치적 사회 적 의미의 맥락들과 경험의 맥락들이 한꺼번에 유입된 채 일정한 의 미의 장을 형성하고 있는 것을 말한다. 코젤렉의 말을 빌리자면 한 단어 속으로 "이 단어가 그 속에서 사용되면서 지칭해 온 수많은 정 치적 사회적 의미와 경험의 맥락들이 한꺼번에 유입'되어 있어야 비 로소 단어는 개념이 된다.3)

풀이하자면, '개념' 은 시대와 상황의 맥락에 따라 다양한 사 람에 의해 사용되면서 개인이나 집단의 경험, 기대, 이해관 계 등에 따라 항상 다의적으로 존재하는, 그래서 항상 그것 이 품고 있는 의미들 사이의 경합과 충돌을 항상 내포하고 있는 논쟁적 단어이다.

이 지점이 바로, 필자들이 ‘체육인’의 개념, 단어, 혹은 어 휘를 '개념史' 적 관점의 개념관(觀) 속으로 포진시켜 놓고 생 각해보는 출발점이다. 질문해보건대, '체육인'이라는 어휘 혹은 용어는 '단어'인가 '개념' 인가? 다시 말해, 그것은 '정 의'해야 하는 대상인 것인가, 아니면 '해석'이 필요한 것인 가? 체육·스포츠학의 학술지형과 실제 속에서 우리는 그것 을 ‘정의'와 ‘해석'의 스펙트럼 사이에 놓아두고 어떻게 접 근하여 탐구할 필요가 있는가? 이하에서는, 이러한 질문들 을 염두에 두고, 필자들이 '체육인'을 왜 '개념史'적 관점의 '개념' 으로 파악하여 해석적으로 탐구하는지에 대한 문제의 식을 피력한다.

\section{왜, ‘체육인’의 개념을 ‘해석’하는가?}

사실, ‘체육인'의 개념은 무엇보다 '정의'가 필요하고 또 시급한 것이 현실이다. 특히 인권과 복지의 이슈를 중심으 로 '체육인' 개념에 대한 명확한 정의가 요청되고 있지만, 정 작 법적 차원의 정의는 너무나 포괄적인 수준에 머물러 있 다. 또한 학계에서도 '체육'이라는 개념의 복잡함과 다의성 으로 인해 ‘체육인’이라는 개념 자체에 대한 논의도 거의 없 는 실정이다. 그렇지만, 이러한 어려움 속에서도 최근 체육

3) Koselleck은 '국가' 개념의 예를 들어 설명한다. '국가'라는 단어가 개념이 되기 위해서는 '통치', '영토', '시민', '입법', '사법', ‘행정', ‘조세'. '군대' 등 독자적인 함의를 갖는 다양 한 실상 혹은 사태들이 그 단어 속으로 포함되어 있어야 한 다는 것이다(Na, 2010a; Kim, 2015).
인 개념에 대한 '정의'를 시도한 유의미한 작업을 찾아볼 수 있는데, 한국스포츠정책과학원이 2019년에 수행한「체육 인 생활실태조사를 위한 기초연구 가 대표적이다.4) '예술 인'과 '농업인'의 개념이 「예술인 복지법」과 「농지법」의 시 행 아래 정의되고 있듯이, ‘체육인’ 의 정책적 정의도 추진되 고 있다는 점에서 큰 의의가 있다고 할 수 있겠다.

우리의 연구는 이렇게 '정의'의 필요성으로 촉발, 점화되 고 있는 학술적 지형 위에, '해석'이라는 또 다른 성격의 지적 안목을 보태고자 하는 것이다. 물론 '체육인'이란 개념이 무 엇인가를 질문하고 그것을 조사하고 정의하여, 체육인이 누 구이며 또 누가 체육인의 대상과 자격이 되는지를 분간하여 가려내는 일은 중요한 일이다. 하지만 곰곰이 생각해보면, '체육인' 의 개념을 정의하는 것은 ‘체육인이라는 것'과 ‘체육 인이 아니라는 것' 사이의 경계를 가르는 것이기도 하다. 아 마도 '개념'이라는 것을 이러한 시각으로 접근하여 탐구하는 (스포츠) 역사학자들은 (스포츠) 역사 속에서 항상 일정한 법 칙과 패턴처럼 존재하고 작동해온 ‘체육인’ 이라는 개념의 의 미와 성격을 발견하고, 그것이 올바르게 사용됐는지를 규정 하고 확인하는 학술적 작업에 관심이 있을 것이다.

필자들의 입장은, 그러한 시각으로 적확한 '정의'를 추구 하는 학문적 시도와 '함께’, '체육인’이라는 개념/단어의 '의 미'와 '쓰임새'에 대해서도 한번 관심을 가져보자는 것이다. 따지고 보면 '체육인'이라는 개념은, 문자 그대로, '체육(體 育)'이라는 분야 혹은 직종의 의미와 '인(人)'이라는 주체 혹 은 대상이 연결된, 딱히 이해하기 어려울 것이 별로 없는 그 런 쉬운 '기표'이다. 그러나 ‘체육인’이라는 개념/단어의 ‘의 미'와 '쓰임새'는 우리의 현실 속에서 ‘체육과 관련된 사람 들 로 단순하게 표현하면서 소통하기에는, 다소 허전하면서 도 밋밋한, 아니 조금 더 부연하여 이야기하자면, 그것이 정 확하게 무엇을 의미하는 것인지 너무나 아리송하고 모호하 기 그지없는 그런 복잡하고 오묘한 개념/단어가 아닐 수 없 다. 마치, 우리가 '자유', '정의', '평등', '국가', '사회', '보 수', '진보' 등의 개념을 아무런 불편함 없이 자유롭게 사용

4) 이 연구에 의하면, '체육인' 개념의 넓은 의미는, "체육 활동 을 업(業)으로 하여 국민의 건강, 즐거움, 여가, 국위선양 등 사회적 가치를 추구하는 데 공헌하는 사람으로서 체육 활동 을 직접 수행하거나 지원 및 지도하는 사람"이다. 또한 좁은 의미로는, "체육 활동을 업(業)으로 하여 국민의 건강, 즐거 움, 여가, 국위선양 등 사회적 가치를 추구하는 데 공헌하는 사람으로서 「국민체육진흥법 제 2 조 제 4 호에 따른 선수 또는 같은 조 제6호에 따른 체육지도자로서 대통령령으로 정하는 사람”으로 정의하고 있다(Jung et al., 2019) 
하고 있지만, 정작 그것의 의미가 정확하게 무엇인지를 생 각해보면, 금방 말문이 막히게 되는 경우처럼 말이다.

이처럼, '체육인' 의 개념 역시 그것 속으로 유입되어 묻어 있고 배어있는 의미의 유동성, 다의성, 중첩성 등으로 인해, 그것을 이해해보고 해석해볼 필요가 있다. 다시 말해, '체육 인'의 개념이 존재하여 작동해온 의미와 쓰임새의 역사, 즉 시대적 조건과 사회적 맥락 속에서 누가 '체육인'이라는 개 념/단어를 누구에게 어떻게 사용하고, 또 그것에 대해 사람 들이 어떠한 의미로 이해하고 소통해왔는지 한번 들여다보 고 이해해보는 것이다.

그렇다고 해서, 이 취지가 ‘체육인’ 개념의 실체와 정의를 밝히고 드러내는 학술적 작업이 무의미하다는 주장으로 오 인되지 않았으면 좋겠다. '체육인'의 개념의 역사성에 주목 하되, 그것이 한국 사회와 언어 담론의 세계 속에서 관계, 매 개, 구성, 형성된 다의적이고 역사적인 의미와 상징의 역동 성 등을 해석해보는 지적 작업도 그것 나름의 의미와 가치가 있는 것이다.

단언컨대, ‘체육인' 개념의 역사적, 정치적, 사회적, 문화 적 의미를 해석해보는 작업이 중요하고 또 가치 있는 이유 는, 그것을 통해 ‘체육인'이 어떠한 사람인지 그리고 그 ‘체 육인'이 속한 사회가 어떠한 사회인지에 대해 잘 이해할 수 있는 영감과 계기를 얻을 수 있기 때문이다. 언어라는 것은 서로가 주고받는 교환의 산물이듯이, 한 개념/단어가 어떻 게 사용되고 또 어떠한 의미로 소통되는지의 '맥락 (context)'을 짚어보면, 그 개념/단어가 지칭하는 바로 그 '대상'에 대해서 뿐만 아니라, 그것을 이야기하는 '화자'에 대해서도 잘 알 수 있게 되는 경우가 많다. 예컨대, 우리가 '미국인'이라는 개념/단어를 '개인주의'와 관련된 특정한 맥락 속에서 자주 사용한다는 점을 생각해보자. 그렇다면, 우리는 그렇게 주고받는 우리의 이야기들로부터, 그들이 어 떠한 개인주의적 사람으로 우리에게 다가오는지에 대해서 뿐만 아니라, 개인주의적인 것과 관련된 우리의 마음과 태 도 그리고 입장에 대해서도 성찰할 수 있다. 우리가 '미국인' 이라는 개념/단어를 사용하면서 주고받는 이야기들 속에 는, '우리'가 '미국인'(들)과 관계하는 다양한 의미 및 상징 의 흔적들이 묻어있기 마련이고, 그것들은 또한 우리의 모 습을 간접적으로 시사하는 것이기도 하다.

필자들의 문제의식 또한 이와 같다. ‘체육인’이라는 개념 /단어는 '체육 분야에 종사하는 사람'으로 소통되는 흔한 '기표'(記表, 시니피앙, denotation)이지만, 그것이 존재해
온 쓰임새의 역사 속에는 그 기표의 사회·문화적 '기의'(記 意, 시니피에, connotation) 즉 다양한 사람들이 다양한 방 식으로 매개하고 관계해온 삶의 의미와 무늬들도 고스란히 묻어있고 스며 있다. 따라서 우리는 ‘체육인'이라는 개념/단 어에 대해 어떤 감정을 느끼고 또 부여하는지, 그것에 스며 있고 묻어있는 사람들의 살냄새는 무엇인지, 나아가 그것이 한국의 체육계와 사회 속에서 어떠한 문화적 의미들로 만들 어지고 빚어지며 매개되고 소통되는지 등에 대해서도 생각 해볼 수 있다. 요컨대, '체육인' 개념/단어의 한국적 의미를 읽어내고, 나아가 그러한 '체육인'들로 구성된 '한국 체육 계' 를 돌아보는 동시에, 바로 그 '체육계' 와 관계해 온 우리 사회의 과거와 역사까지도 함께 성찰해볼 수 있는 것이다. 필자들은 이러한 역사적이고 해석적인 접근이, '체육인' 개 념/단어를 '정의'하는 작업 못지않게 '체육인'에 대해 잘 알 수 있게 되는 또 하나의 유의미한 방식이라고 믿는다.5)

\section{'체육인' 개념을 '해석'하는 틀과 방법}

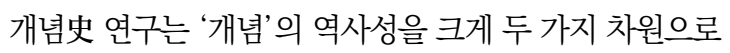
구분하여 인식한다. 하나는 공시적 차원이고, 다른 하나는 통시적 차원이다. 결국, '개념'이라는 것은 특정한 시대의 특정한 사람들에 의해 만들어지고 소통되는 '공시적' 산물 임과 동시에, 역사적 흐름 속에서 끊임없이 그 의미의 변화 를 겪게 되는 '통시적' 산물이다.

개념의 '역사적' 의미를 탐구하는 작업도 두 가지 차원으 로 구분하여 진행할 수 있다. 먼저, 공시적 분석은 한 개념의 시대적 의미를 파악하는 것에 관심을 가지고, 그것이 특정 한 시대적 조건과 배경 속에서 어떠한 언어적 기능을 수행하 고 또 어떠한 사회적 힘과 영향력을 발산하며 매개되는지를 탐구하는 것에 초점을 둔다. 반면에, 통시적 분석은 개념의 역사적 유의미성을 보다 긴 시간적 범위 속으로 위치시켜놓 고, 그것의 의미가 어떠한 흐름과 양상으로 변화, 굴절, 전 환, 전복, 지속, 혹은 (재)강화되는지 등을 종단적으로 추적 하여 조사, 정리하는 작업이다( $\mathrm{Na}, 2010 \mathrm{a}, 2014)$. 이러한 두 차원의 연구, 즉 공시적 분석과 통시적 분석으로 진행되 는 연구들이 축적될 때, 비로소 한 개념의 역사적 의미를 해

5) 지금까지 논의한 단어와 개념의 구별을 토대로, 이하부터는 '체 육인'을 ‘단어/개념'이 아닌 '개념'으로 표기하면서 서술한다. 
석적으로 탐구하는 하나의 개념史 프로젝트가 완성된다.6) 간단히 말해, 이 연구는 ‘체육인' 개념의 개념史 프로젝트 를 만들어가는 출발점으로 기획한 하나의 공시적 분석이다. 구체적으로, 필자들은 광복 이후부터 제3공화국이 출범하 기 이전까지의 시기(1945-1961)7)에 주목하는데, 그 이유 는 이 시기를 ‘체육인'이라는 어휘/용어가 일간지 신문 기사 들 속에 본격적으로 등장하여 소통됨으로써, 그것의 '사회 적 대표성'이 어느 정도 정착, 확립된 시기로 추정할 수 있기 때문이다. 한 개념의 사회적 대표성은 "보통 사람들이 사용 [하는] 일상언어”를 통해 가늠해볼 수 있는데 $(\mathrm{Na}, 2003)$, 필자들은 일간지 신문의 기사들이야말로 '체육인'의 개념 속에 사람들의 일상적 경험과 기대가 어떻게 반영되고 수렴 되는지를 파악하고 해석하는데 유용한 자료가 될 수 있다고 판단한다. 그리고 이 시기에 주목하는 공시적 분석을 진행 함으로써, '체육인' 개념의 개념史 프로젝트를 완성해 나가 는 출발점으로 삼고자 하는 것이다.

자료 수집 및 방법과 관련해서, 〈네이버 뉴스라이브러 리>에서 제공하는 데이터베이스를 통해 '체육인'으로 검색 하여 총 338편의 기사(1945-1961)를 수집하였다. '체육 인’의 어휘/단어/개념이 등장하는 1945년 이전의 기사는 단 3건에 불과하였으며, 그것이 사용되는 맥락 역시 체육과 관련된 주체들을 단순하게 지시하는 경우로 판단하여 분석 대상에 포함하지 않았다. 마찬가지로, 총 338편의 기사 중 에 '체육인' 의 기표가 단순히 '체육과 관련된 주체' 혹은 '체 육에 종사하는 사람' 등을 지시하는 경우, 예컨대 '체육인 다 수', '연희 체육인' 등의 표현으로 기술되어 있는 기사들 또 한 배제하였다. 최종적으로, ‘체육인’의 개념이 특정한 서사 구조 속에서 의미 작용을 하는 언어적 요소로 기능/역할하 고 있는 칼럼형 기사 140 편을 분석 대상으로 삼았다.

필자들이 신문 기사들을 읽고 해석하는 과정에서 가장 중 점을 둔 사항은, '체육인'의 개념이 어떠한 언어적 '맥락'과 사회·문화적 '상황' 속에서 언급, 사용, 활용되고 의미화되 어 전송되는가의 쟁점이다. 특정한 개념의 의미와 역사성을

6) Koselleck은 '민족', '문명', '제국주의', '전쟁' 등과 같은 115 개의 기본 개념 항목을 선정하여 7,000 쪽에 걸친 방대 한 분량으로 서술한 『역사 기본개념』이라는 일종의 개념 사 전을 편찬하였다. 본문에서 언급한 '개념사 프로젝트'를 '체 육인'의 개념과 연관시켜볼 때, '체육인' 개념에 대한 공시적 분석과 통시적 분석이 결합된 일종의 '체육인 개념사 프로젝 트'를 상상할 수 있다.

7) 1961 년을 경계로 설정한 이유는 이어지는 '각주 7번'에서 설 명하였다.
해석하는 데 있어 이러한 '맥락'과 '상황'을 고려하는 것이 중요한 이유는, 하나의 개념/단어도 그것이 어떠한 '맥락' 과 '상황'에서 사용되느냐에 따라 그 의미가 완전히 달라질 수 있기 때문이다. 언어학의 관점에서, 특정한 대상(text)을 '해석'한다는 것은 그것의 객관적인 실체나 모습을 있는 그 대로 나타내거나 묘사하여 설명하는 것이 아니다. ‘해석'의 작업은 대상(text) 그 자체가 지시하는 내용에만 관심을 가 지는 것이 아니라, 그것을 배태하거나 혹은 그것과 다양한 방식으로 관련되어 있는 '맥락(context)'을 고려하여 그것 이 매개하고 내포하는 상황적이고 관계적인 의미, 상징, 효 과, 영향력 등도 함께 읽어내는 것이다.

이 '맥락적 해석'이야말로 개념사학자들이 개념史 연구 의 요체로 지목하여 강조하고 있는 핵심 아이디어이다. 예 컨대, Koselleck은 "텍스트 전체의 문맥, 저자와 독자의 상 황, 그 시대의 정치, 사회적 상황, 언어 공동체를 이루는 동 시대인들과 이전 세대의 언어 관행과 용법 등이 고려되어야 하며, 나아가 더 구조적인 경제학적, 사회학적, 정치학적 문 제제기들이 수반"되어야 함을 피력했다. Koselleck의 제자 이기도 한 Rolf Reichardt 역시 "개념의 사회적 대표성, 다 시 말해 개념에 담긴 의미체계의 사회적 영향력을 읽을 수 있어야 한다"는 점을 강조하였다( $\mathrm{Na}, 2003)$. 결국, "개념' 이라는 것은 그것 자체로 순수하게 존재할 수 없는, 아니 오 히려 그것의 사용 및 소통과 연관된 맥락 속에서 이해되고 또 해석될 수 있다는 것이 요지다.

필자들이 진행하는 해석의 작업 역시 '체육인' 개념에 대 한 언어적 사용과 그 효과 등을 사회적 실재를 구성하는 다 양한 맥락과의 관계를 고려하여 이해해보는 것이다. 즉 과 거를 살아간 사람들이 ‘체육인'이라는 개념을 사용하면서 표현하고자 했던 여러 의미의 행간이 무엇인지, 또한 그들 이 어떠한 방식으로 그들의 경험, 기대, 욕망, 희망 등을 그 개념 속으로 유입시키며 의미 부여했는지, 아울러 '체육인' 의 개념을 활용하는 서사 속에 어떠한 가치관, 심성 및 태도, 사고방식, 세계관 등이 흐르고 있는지 등을 사유하면서 해 석하는 것이다.

그렇다면, 이러한 해석적 작업을 수행하기 위해 파악하 고 고려해야 하는 구체적인 맥락은 무엇인가? ‘체육인'의 개 념은 어떠한 언어적 맥락과 사회·문화적 상황 속에서 사용, 활용되었으며, 그 언어적 의미와 사회적 효과 및 영향력은 어떠했는가? 조금 더 구체적으로, 광복 이후부터 제3공화국 이 출범하기 이전까지의 시대적 배경과 조건 속에서 사람들 
이 말하고 이야기하며 소통한 '체육인'의 의미는 어떠한 상 징과 표상을 담지하고 있는 것이었는가? 또한, 그것은 당시 의 한국 사회와 스포츠 세계에 어떠한 언어적 효과와 사회적 영향력을 제공하거나 매개하는 것이었는가?

필자들이 주목하는 핵심 '맥락' 은, 해방공간과 건국 초기 의 시대적 배경과 조건 속에서, 한국 사회가 새로운 주체로 서의 ‘국민'을 호명하여 구축하던 이른바 주체 형성의 담론 적 실제가 등장하기 시작한 국면이다. 꿈과 희망 그리고 혼 란과 소요가 동시에 존재하고 있었을 당시, 한국 사회는 안 으로 새로운 국가 발전의 기틀을 마련하면서, 밖으로 냉전 체제의 국제질서에 적응해가던 시기였다. 이러한 과업을 수 행하는 민족적/국가적 개인으로서 '국민'이라는 이름의 주 체가 다양한 영역과 분야에서 호명되기 시작하였는데, 특 히, 신문 및 잡지와 같은 출판 미디어는 이러한 '국민' 주체 의 형성을 추동하고 견인하는 이른바 주체화의 담론이 생 산, 전송, 수용되는 지배적 공론장이었다(Hong, 2019; Jeon, 2005; Shim, 2016).

단언컨대, '체육인' 의 개념이 본격적으로 등장하여 소통, 정착된 흐름과 과정을 이해하는 것 역시, 이러한 민족적-국 가적 차원의 새로운 주체가 호명되던 '맥락' 속으로 위치시 켜놓고 이해할 필요가 있다. 당시의 체육·스포츠계는 새로 운 국가 건설과 사회적 기반의 기틀이 조성되는 시대적 배경 속에서 '체육'의 이상과 가치를 꿈꾸고 상상하며 실천하는 염원을 담아, 새로운 '체육 한국' 의 출발을 위해 기지개를 켜 는 상황이었다(Hong, 2011; Kim \& Son, 2019). 몇몇 유 의미한 발자취들을 더듬어보면, 광복의 기쁨과 함께 이상백 을 중심으로 조선체육동지회가 발족되었고, 이어서 여운형 을 회장으로 하는 조선체육회가 재건되었으며, 이후 건국과 함께 대한체육회의 출범으로 '체육 한국' 의 발전을 견인하 는 조직과 기구가 마련되었다. 경기력의 측면에서도, 서윤 복 선수가 1947년 제51회 보스턴 마라톤대회에서 우승한 것을 계기로, 이듬해 런던에서 개최된 올림픽에 건국 이후 처음으로 독립 국가의 자격으로 출전하여 좋은 성과를 거두 었으며, 그리고 1950 년에는 함기용, 송길윤, 최윤칠 세 명 의 선수가 보스턴마라톤대회의 $1,2,3$ 위를 휩쓰는 쾌거를 올리기도 하였다.

‘체육인'의 개념은 이러한 체육 관련 조직 및 경기의 실제 와 관련된 사건과 현상 등을 보도하거나 탐사하는 기사들 속 에서 자주 등장하고 있는데, 그것이 언급되는 양상과 패턴 에는 크게 두 가지 기술적(descriptive) 특징이 두드러짐을
알 수 있다. 첫 번째 특징으로, ‘체육인'이라는 개념이 '사회 적 대표성'을 띠는 수준의 대중적 어휘/용어로 '정착' 되었다 는 점을 감지할 수 있다. 예컨대, 한국 전쟁 기간 중 진행된 “체육인 등록”(Dong-A Ilbo, 1951, 1, 14)과 “체육인[팀] 과 기자[팀]”의 친선 축구 정기전(Kyunghyang Shinmun, 1957. 6. 27)과 같은 기사들의 제목들이 자주 등장하고 있 다는 점, 그리고 “체육인"이라는 이름으로 체육 관련 주요 인사들의 동정을 전하는 코너도 개설, 운영되었다는 점 등 을 통해 충분히 유추해볼 근거가 있다(Kyunghyang Shinmun, 1958. 9.5).

다른 하나의 패턴은, '체육인'의 개념이 포함된 서사가 항 상 특정 주체들의 ‘집단적'이고 '집합적'인 성격을 의미하고 논의하는 특징을 띠고 있다는 점이다. ‘체육인’ 이라는 어휘/ 용어 자체가 특정한 사람을 지칭하는 대표성을 띠기 때문이 기도 하겠지만, 특수하고 개별적이며 개인적인 사건과 현상 도 ‘체육인'이라는 개념이 함께 사용되어 연결되는 순간, 서 사의 구조는 즉시 집단화되면서 집합적인 차원의 정체성을 띠는 국면으로 전환된다. 이 지점이 바로, 필자들이 '체육인' 개념의 쓰임새를 한국 사회 전반에서 일어나고 있던 주체 형 성의 담론과 연결하여 맥을 짚어보고자 하는 곳이다. 즉, 해 방공간과 건국 초기, 한국 사회가 호명하여 주조하고 있던 새로운 민족적-국가적 주체 형성의 담론이 '체육'을 포함한 다양한 분야의 실제 속으로 스며들어 지역적이고 미시적인 통치성을 행사하는 언어적 현상을 들여다보는 것이다. ${ }^{8)}$

이러한 판단과 접근방식을 토대로 필자들이 진행한 해석 의 주요 골자는 다음과 같다. 먼저, '체육인'의 개념은 해방 공간과 건국 초기의 시대적 조건 아래 역사·정치·사회·문화 적으로 호명되어 형성되던 새로운 민족적/국가적 주체의 표 상이 '체육'이라는 실제 속에서 관계되고 매개되어 구현된 하나의 담론적 산물이다. 다시 말해, 자신들의 집합적 전문 성과 집단적 소속감을 공유하는 특정 주체들이 당시의 한국 사회가 요구하고 있던 새로운 주체의 표상을 그들이 몸담아 관여하고 있는 분야인 '체육' 의 실제 속으로 투영하여 상상 하면서 공유한 언어적 구성물이 바로 ‘체육인’의 개념이다.

8) 이 지점에서, 왜 필자들이 공시적 분석의 시기를 1961년까지 로 국한하는지 언급하는 것이 좋을 것 같다. 상술하였듯이, 해방공간과 건국 초기에 ‘체육인'의 개념이 활용되는 주요 맥락은 민족-국가적 주체를 호명하는 담론과 깊은 관계가 있다. 이러한 관점에서, 필자들은 군사정부로 상징되는 제3 공화국의 출범이 지배적 주체화 담론의 교체 혹은 대체가 일 어나는 일종의 전환적 국면 혹은 변곡점이라 판단하였다. 
일제 강점기 시절의 고통과 아픔을 극복하고, 건국의 사명 에 부합하는 발전의 초석을 다지고 이행하는 새로운 민족적 -국가적 주체의 체육적 이상형(ideal type), 즉 체육적 주체 로서의 ‘국민'이 바로 ‘체육인'이라는 개념이 탄생한 공시적 차원의 사회·문화적 맥락이다.

'체육인' 의 탄생, 즉 새로운 '체육 한국' 의 건설을 주도하 고 견인하는 민족적/국가적 주체로서 ‘체육인'이 호명되는 것은 곧 집합적 정체성의 본질과 실체를 규정하는 성격을 담 고 있다. '국민'이라는 새로운 주체를 호명하는 담론의 실제 가 사회 구성원들의 집합적 정체성을 부여하고 형성하여 결 속하는 과정을 강하게 내포하고 있듯이, '체육인'이라는 주 체화된 개념 역시 특정한 사회적 집단의 주체들이 함께 이야 기하고 소통하면서 공유하고 결속하게 되는 집합적 정체성 의 (상상된) 표상이다.

여기에서 잠시, 누가 ‘체육인’ 의 개념을 선점하여 발화하 는지에 대한 쟁점에 대해 생각해볼 필요가 있겠다. 그들은 바로, ‘체육인'이라는 집합적 표상을 사용, 소통, 공유함으 로써 자신들의 집단적 정체성을 특정한 방향으로 이끌어나 가는 것을 선점, 기획, 추진할 수 있는 '사람들' 이다. 다시 말 해, ‘체육인' 이라는 개념 속으로 집어넣을 수 있는 지배적 의 미(혹은 이데올로기)를 직접 생산, 전송하거나 개입하여 유 인, 전환, 대체하는 힘을 가지고 있는 '사람들' 이다. 결국, 담 론 생산의 헤게모니를 가지고 있고 또 그것을 행사할 수 있 는 특정한 집단적 주체들이 그들의 집합적 정체성을 특정한 방향으로 구성/형성해나가는 언어적 전략으로 활용하는 담 론의 핵심적인 요소가 바로 '체육인' 의 개념이다.

필자들이 해석한 결과는 크게 두 가지이다. 첫째, '체육 인' 의 개념은 특정한 (체육 관련) 사회적 집단의 주체들이 자 신들의 집합적 정체성을 특정한 방식으로 규정하고 정의하 는 자기-재현의 언어이다. 구체적으로, '체육인'의 개념 속 으로 유입되는 지배적 의미는 주로 '체육' 혹은 '스포츠'야 말로 세계와 공정하게 경쟁하여 승리함으로써 한국을 알릴 수 있게 되는 문화 부문의 효자라거나, ‘체육인'(들)이야말 로 순수하고 비정치적이며 강직한 사람들이자 건강한 신체 와 건전한 정신의 소유자가 되어야 한다는 내용이다.

둘째, 이러한 ‘체육/인'의 지배적 의미/이데올로기는 다 시 두 가지 감정이 교차, 대립하는 패턴의 서사 구조를 통해 강화된다. 한편으로, '체육인'의 개념은 체육인 집단 및 체 육계 조직(실제)의 빛나는 성과와 업적을 표현하고 확인하 는 서사 속에 등장하면서 '자부심과 긍지(pride)' 의 감정을
공유하는 과정을 통해 '체육인'의 집합적 정체성을 긍정적 으로 강화한다. 다른 한편으로, '체육인'의 개념은 부정적이 고 불미스러운 사건과 행태들을 지적하고 비판하는 서사 속 에 등장하면서 '수치와 부끄러움(shame)'의 감정을 성찰하 는 과정을 통해 다시금 '체육인’ 의 정체성을 복원 혹은 재인 식하는 효과를 발휘한다. 종합하자면, 이른바 자부심/긍지 와 수치/부끄러움의 정치학(politics of pride/shame), 즉 두 가지 대립적 감정이 연속적으로 교차하면서 집합적 정체 성을 관리, 구축, 강화하는 (자기) 재현의 정치학이 곧 ‘체육 인'의 개념이 사용되고 활용되면서 만들어내는 수사적 효과 이자 언어적 힘이다.

이상의 주장을 구체화하기 위해, 이하의 장에서는 먼저 '체 육인'의 개념이 자부심과 긍지의 감정을 집합적으로 공유하는 서사들 속에 등장하여 기능하는 양상부터 서술하고자 한다.

\section{신문 기사 속 '체육인'의 긍정적 담론: '자부심/긍지'를 집합적으로 상상, 공유하는 민족-국가적 주체}

‘체육인'의 개념이 사용, 이해, 소통되는 지배적 방식은, 그것이 새로운 민족-국가적 주체의 체육적 표상을 재현하고 구성하는 서사의 핵심어로 등장하여 기능한다는 것이다. 해 방공간과 건국 초기, 한국 사회는 한편으로 국가 발전의 기 틀을 마련함과 동시에, 또 다른 한편으로 그러한 과업을 추 진하는 '국민'이라는 새로운 주체를 다양한 영역과 분야에 서 호명하고 있었다. 체육 분야 역시 ‘체육계’라는 이름 아래 이러한 주체화 담론들이 양산되었는데, '체육인' 의 개념은 그러한 서사와 담론 속에서 다양한 의미/상징/가치 등과 연 결되고 결합하면서 특정한 주체의 모습을 표상하는 핵심어 로 등장한다.

필자들은 이러한 서사적 패턴을 새로운 건국 주체로서의 ‘체육적' 주체가 만들어지고 구성되는 일종의 주체화 담론 으로 틀 짓는다. 이러한 담론 속에서, '체육인'의 개념은 크 게 두 가지 의미의 주체를 표상한다. 하나는, 국가적 차원의 표상으로, '체육인'의 개념은 민족의 강인한 체위와 우수성 을 상징하고, 세계를 향해 대한민국의 건재함을 알리며 국 위선양에 앞장서는 주체이다. 그리고 다른 하나는, 사회적 차원의 표상으로, “체육 정신”, “운동 정신”, “스포츠맨십” 
등으로 표현되는 자유·민주적 시민으로서의 행동 양식, 태 도, 가치관, 품성 등을 체화하여 실천하는 모범적 시민으로 서의 주체이다.

종합하자면, '체육인'의 기표는 국가적 차원의 (체육적) 주체와 사회적 차원의 ‘체육적' 주체를 동시에 접합하고 있 는 표상이다. 즉 특정한 집단의 주체들이 해방공간과 건국 초기의 시대적 조건 속에서 그들의 집합적 정체성을 '국가 적'이고 '사회적' 차원을 고려하여 구성, 형성해나가는데 활 용한 주체화의 언어적 산물이 곧 ‘체육인'의 개념이다.

이하에서는, 먼저 ‘체육인'의 개념이 민족-국가적 주체의 표상으로 서사화되는 내용과 양상부터 살펴보고, 이어서 사 회적 차원에 대한 논의를 진행한다.

'체육인'의 개념이 국가적 차원의 표상으로 서사화되는 주요 골자는, 1) 일제 강점기 시절 손기정 선수의 활약으로 대표되는 빛나는 체육 전통을 계승하고, 2) 전 민족의 강인 한 체위 향상과 우수성을 상징하고 대변하며, 3) 세계를 향 해 대한민국의 건재함을 알리는 국위선양의 주체가 바로 ‘체육인'이라는 의미이다. 특히, 이러한 아이디어와 메시지 는 ‘체육인' 의 개념을 통해 마치 구호처럼 사용되고 있으며, 집합적 주체의 사명, 결의, 책무 등으로 연결되는 감정적 어 조를 드러낸다.

무엇보다, '체육인'의 개념은 삼천만 동포들의 자랑이기 도 했던 손기정 선수의 직속 후예들을 의미한다. 예컨대, 당 시, 조선빙상경기협회 이사 최용진의 칼럼, "강인성을 보이 라”에서는, 해방을 맞이하고 새롭게 출발하는 “체육인'의 희 망을 손기정 선수와 같은 이전 체육인의 업적을 되살리는 것 에서 찾고 있다.

우리 체육인은 오랫동안 누구보다도 강렬하게 국가 없는 비애를 심 각히 맛보았고 침울한 역경에서 누구에게도 지지 않는 눈물겨운 분 투를 하여 왔으며, [...] [일제 강점기] 생활의 위협 중에서 암석을 뚫 고 솟아오르는 초목과도 같이 생존력과 투쟁력의 강인성을 전 세계 에 자랑한 사실은 여러 번 있었으며 우수한 민족의 영웅이 연달아 나오는 가운데 특필대서를 자랑할 바는 손기정 선수의 세계적 마라 톤 우승이 공인받은 사적이다. 그는 절망 상태에 빠진 우리 동포들 에게 생명수를 주는 동시에 민족적 자부심을 환기시켰으며, 세계에 삼천만 민족의 존재와 우수성과를 한꺼번에 자랑하였던 것이다. 이 와 같이 비분한 가운데에서 찬연한 역사를 지은 체육인의 희망은 누 구보다도 절대하다(Chosun Ilbo, 1946. 3. 5a.).

바꿔 표현하자면, 건국과 함께 찾아온 ‘체육인' 의 희망은 손
기정 선수의 ‘슬픈 승리’이자 자랑스러운 과거를 다시 이 땅 위에 되살리는 것이며, 그것이 곧 ‘체육인' 의 사명이자 책무 라는 것이다.

이러한 ‘희망’의 서사가 ‘체육인’ 의 개념을 통해 표출되고 확인되는 것을 잘 살펴볼 수 있는 또 하나의 중요한 사례는 1947년 제51회 보스턴 마라톤대회에서 서윤복 선수가 우 승한 사건이다. 대회 한 달 전, 유수의 “애국단체”들은 한국 을 대표해서 보스턴으로 가게 될 손기정, 남승룡, 서윤복의 출국을 축복하고 격려하는 메시지와 성금을 담은 공동성명 을 ‘체육인'의 이름 아래 다음과 같이 발표하였다.

세계마라톤대회에서 손, 남, 서 세 선수를 특별히 초청한 것은 배달 민족의 찬란한 역사와 문화를 논증하는 것이며 왜적의 질곡 속에서 역사적 투쟁을 한 세계의 체육인의 귀감인 손기정, 남승룡 선수의 해방을 축복하는 것이며, 한층 더 조선인의 독립지주민임을 국제적 으로 보장하는 기회다. 세 선수의 참, 불참은 명년도 세계 올림픽대 회에 독립국민의 전위인 우리 체육인들에 참, 불참을 결정하는 중대 한 계기이다. 우리는 조국의 독립민족의 자유를 위하여 비장한 결의 로 세 선수를 거족적으로 성원할 뿐이니라. 각계각층에서 단기간에 성금을 각축하여 경제문제로 참가 못 하게 되는 민족의 수치를 결단 코 면하여야 한다. 우리 각 단체는 공동으로 각 조직을 통하여 담당 한 성금 거출을 완수하며 사상의 좌우를 월탈하여 악질적 정객 언론 기관 모리배, 호취객, 독립운동방관자들의 철저한 반성을 요구하 며, 이 땅의 젊은이들을 완비한 원호하에 승리의 월계관을 획득하여 체육을 통한 민족외교에 성공토록 국민적 책임을 완수하기를 맹세 한다(Dong-A llbo, 1947. 3. 22.).

‘체육인'의 희망과 염원은 서윤복 선수의 승리로 큰 결실을 거두게 되었는데, 당시의 사람들이 이 사건에 대해 어떠한 의미부여를 했는지는 그동안 여러 연구와 대중 미디어를 통 해 익히 알려진 바 있다.

예컨대, 동아일보는 체육 관련 주요 인사들의 감격이 담 긴 목소리들을 실어서 보도하였는데, 당시의 문교부장이었 던 유억겸은 "서[(윤복)]선수의 우승은 우리 관계자만의 기쁨 이 아니다. 삼천만 전부의 것이다”라고 치하했다(Dong-A Ilbo, 1947. 4. 22a.). 미 군정의 하지 중장도 “용감하고 백 전 불굴하는 의지로써 이 역사적 대승리를 획득한 것으로, [...] 이 승리는 세계독립국가의 일원으로 엄연히 공진할 수 있게 하는 큰 힘이 될 것”이라고 축하하였다(Dong-A Ilbo, 1947. 6. 24.). 서윤복 선수의 일생과 1947년 보스턴 마라 톤 대회의 한국선수 출전을 탐구한 Yim \& Cho(2009)도 "보스턴 대회 재패는 미 군정 치하로부터의 자주독립을 열망 
하는 한(韓) 민족의 염원을 발산하여 달성한 것이었으며, 동 시에 마라톤 한국의 위상을 격상시켜 '세계 속의 KOREA'을 각인시키는 유일한 통로였다고 해도 과언이 아닐 것이다”라 고 의미부여하고 있다(Yim \& Cho, 2009).

이러한 민족적, 국가적 경사를 자축하고 기념하는 다양 한 목소리들 속에서, '체육인'의 개념은 서윤복 선수의 승리 가 상징하고 표상하는 집합적 정체성의 의미를 다시금 확인 하고 결속하는 구호로 제시된다. 예컨대, 경향신문은 "체육 조선의 진로”라는 제목 아래, 서윤복 선수의 승리가 “마라톤 왕국의 대의와 명분을 만천하에 뽐내” 게 된 것임을 강조하 면서, 다음과 같이 '체육인' 의 개념을 '체육도(道)'라는 개념 과 함께 언급하고 있다.

투지와 나라에 충성하고 동족을 사랑하는 단결력과 의협심을 생명 으로 하는 체육도를 다하자는 것이 마라톤 왕국으로 전세계를 감격 시킨 우리 체육의 이념이오 취할 바 진로다. [...] 앞날의 우리 체육 인은 오직 합치고 뭉치어 세계를 대상으로 한국 남아의 우수성을 발 휘하기에 전력을 다할 뿐이다(Kyunghyang Shinmun, 1947. 4. 27.).

비슷한 어조로, 동아일보의 한 칼럼도 서윤복 선수의 승 리를 통해 국가건설과 민족 외교의 주체로서 ‘체육인'을 호 명하고 있다.

건전한 국가는 건강한 국민에 재(在)하고 건강한 국민은 "스포츠도 (道)"의 장려에 존(存)함은 [두말할 필요가 없다.] [...] “스포츠”야 말로 국력증강의 요소인 동시에 국위선양에 가장 첩경임도 또한 [명 확한] 사실이다. [...] 이제 조국광복과 동시에 우리 “스포츠맨"에게 도 건전한 국가건설과 건실한 민족외교에 이바지할 기회가 부여되 고 보스턴 [...] 대공에 우리 국기가 [휘날리고] 우리 건아의 면목이 [올라갔음은] 실로 눈물겨운 [...] 일이다(Dong-A Ilbo, 1947. 4. 22b.).

‘체육인'의 개념이 민족-국가적 주체로 호명되는 언어적 담론의 실제는, 3 년 후 1950 년 제 54 회 보스턴 마라톤대회 에서 함기용, 송길윤, 최윤칠 세 선수가 각각 $1,2,3$ 위를 휩 쓴 사건을 보도하고 이야기하는 서사 속에서도 자주 등장하 였는데, 특히 국제관계와 외교적 측면에서 큰 의미를 부여 하는 기사들을 많이 볼 수 있다. 대표적 예로, 경향신문은 " 대외선전과 마라톤선수”라는 제목의 장문의 칼럼을 상, 하 편으로 구분하여 2회에 걸쳐 게재하였는데, 그 칼럼은 세 선
수의 승리를 “대외선전의 금자탑”을 쌓은 것으로 비유하면 서, 이러한 국제외교의 선봉 역할을 하는 것이야말로 민족국가적 주체로서 '체육인'이 짊어지고 가야 할 책무라는 점 을 다음과 같이 피력하고 있다.

우리의 스포츠는 보스턴 대회에 그칠 것이 아니다. 앞으로도 민주세 계의 우방 국가 사이에 스포츠의 진출과 초빙이란 교환행사가 있어 야 한다. [...] 스포츠 교류 없이는 국제우호도 국제외교도 성립될 수 없다. 그것은 민족과 민족 사이에 주고받는 감정이 국제우호와 국제 외교를 결정하는 하나의 척도로서의 기본요소이기 때문이다. [중 략] 스포츠와 [...] 문화 일반은 국제우호와 국제외교의 기본작용이 될수 있고 대외선전의 기본요소로 되어 있다는 것을 우리는 재인식 해야만 할 이때 체육인이나 문화인의 책무는 크다 하지 않을 수 없 다. 우리의 건전한 스포츠는 나이 이십일 이세의 약관 청년들에 의 하여 세계에 선양되었다. [...] 마라톤의 승리는 [...] 대외선전의 승 리를 의미한다. 그리고 이런 승리는 앞으로도 계속되어야 한다. 문 화의 우세 그것은 앞으로 반듯이 있어야 한다. [...] 함기용, 송길윤, 최윤칠 선수가 보스턴 원두에 쌓은 대외선전의 금자탑을 지금 내맘 속에 그리면 그릴수록 나는 흥분하고 통쾌해진다(Kyunghyang Shinmun, 1950. 5. 10.).

이처럼, ‘체육인’의 개념은 “체육계”, “체육도(道)”, “스포 츠도(道)", “스포츠맨” 등의 개념/단어들과 연동하여 결합하 면서 민족주의적이고 국가주의적인 성격의 서사와 담론을 구성하는 핵심어로 등장한다. 다시 말해, '체육'의 실제가 민 족주의와 국가주의 담론으로 포섭되는 맥락 속에서, '체육' 의 의미와 가치 그리고 민족-국가의 이념과 위상을 서로 연 결하는 상징적 개념이 바로 '체육인'의 개념이다. 구체적으 로, 그것은 '자주독립' 의 이상과 '국위선양' 의 과업을 체육의 실제 속에서 몸소 실행하고 구현해내는 투사로서의 집합적 주체이다. 그러한 개념 사용은 주로 그것을 발화하는 주체를 포함한 “우리”라는 수식어와 함께 동반되는데, 이러한 집단 적 주체화의 개념은 '체육인' 의 기표 안으로 집합적 정체성 을 공유하는 주체들의 사회적 공헌을 공표하여 확인하고, 또 그들의 결속을 도모하는 자기-재현의 정치적 구호이다.

'체육인' 의 개념이 국가적 차원의 주체를 표상하는 내용 은 이 정도로 갈무리하고, 지금부터는, 사회적 차원으로 주 체로 의미화되는 양상을 서술하고자 한다. 간단히 말해, "체 육인'은 건전한 정신과 건강한 신체를 소유한 이상적 주체 인데, 구체적으로 두 가지 의미를 표상한다. 하나는, 1) 체육 의 '대중화'를 견인하며 민족 체위의 향상에 앞장서는 리더 이자 교육자이며, 다른 하나는, 2) 체육 정신", "운동 정신", 
“스포츠맨십” 등을 체화하여 실천하는 순수하고 긍정적이 며 강인한 국민이다. 이러한 서사 속에서, ‘체육·스포츠 정 신' 은 자유민주주의 사회를 이끌어가는 민주적 시민 정신의 메타포로, 그리고 그러한 민주주의(=스포츠) 정신을 소유하 여 실천하는 ‘체육인'은 이상적이고 바람직한 자유 민주국 가 대한민국의 국민적 모델로 상징된다.

일단, 이러한 사회적 차원의 서사가 어떠한 골격으로 구 성, 전개되는지 잘 알 수 있는 하나의 대표 사례부터 소개하 는 것이 유익할 것 같다. 1946년 10월 20일, 해방 정국에서 미 군정 문교부장을 맡았던 유억겸은 경향신문에 “조선체육 계에 기함”이라는 제목의 칼럼을 기고하였는데, 주요 대목 을 발췌하며 보면 다음과 같다.

한 국가의 소장이 국민의 기백의 강약에 달려 있음은 [...] 현실이 증 명하여 주는 바이다. 그러면 국민의 [...] 기백은 무엇으로써 함양할 수 있을까? [...] 무엇보다도 그 국민의 체위 향상을 도모함으로써 소기의 결과를 거둘 수 있다고 믿는다. 곧 건전한 신체랑 건전한 정 신을 가질 수 있으며, [...] 기백을 가진 국민이라야 그 조국을 잘 지 킬수 있고] 또 그 조국을 번영케 할 수 있다. 이러한 관점에서 나는 우리 체육계에서는 [다양한] 종류의 운동경기일지라도 국민 체위의 항상을 도모키 위하여 이의 대중화를 주창하는 동시에 우수한 경기 자 선수를 대량으로 양성하여 분야에 따라 대중체육을 지도하게 하 는 한편 [...] 경기자나 지도자를 막론하고 운동경기를 통하여 인격 을 도야하며 공정한 행동을 하는 습관, 단결력, 인내심, 용, 진력, 판 단력, 희생심을 배양하여 사생할 뿐만 아니라 공생활에 이르기까지 그 진가를 발휘하기를 바라며 만난을 무릅쓰고 우리 체육계가 비교 적 질서 정연히 발전되어감을 보고 들고 생각할 때마다 체육인들에 게 감사하는 바이다(Kyunghyang Shinmun, 1946. 10. 20).

덧붙이자면, 문교부장 유억겸은 해방 직후 국가 건설과 이를 위한 사회적 주체의 형성 요건으로 민족주의적 관점의 생활개선 혹은 신생활을 강조한 학자이기도 하다. $\operatorname{Im}(2012)$ 의 설명에 의하면, 그는 "건전한 국가는 건전한 민족에 있을 것”이라고 주장하며, 국가와 민족을 공동체와 주체의 관계로 연결하고, 그것을 실천하는 수단으로서 사회적 생활의 개선 을 주장했다. 이러한 맥락에서, ‘체육'이 민족의 체위를 향상 하고 나아가 “건강한 신체와 건전한 정신"을 가질 수 있도록 이끄는 이상적이고 바람직한 수단이라는 유억겸의 주장은, '체육'이 곧 국가건설을 도모하는 사회적 구성원들이 그들의 삶과 일상 속에서 새롭게 이식하면서 변화시켜나가야 할 '신 생활' 의 주요 요체라는 의미로 해석할 수 있다.

'건강한 신체와 건전한 정신'의 문구는 비단 유억겸만의
개인적 표현이 아닌, 당시의 시대적 상황 속에서 흔히 소통 되는 일반적인 상투어라고 해도 과언이 아닐 것이다. 그리 고 이 시대적 표어는 사회적 주체로서의 '체육인'을 호명하 는 서사와 담론 속에서 예외 없이 등장한다. 예컨대, 조선탁 구협회장 조동식은 체육을 “통일의 원동력"으로 지목하고, "체육인으로서 기대되는 것은 마음과 몸을 합한 정신적 통 일이 된 건전한 정신의 소유자가 되는 동시에, 또한 건전한 육체의 소유자가 되어 달라는 부탁이다"라고 호소하였다 (Chosun Ilbo, 1946. 3. 5b). 또한, “유도의 정신"을 소개 한 조선일보의 한 칼럼에서는 "인류 공동의 이념[,] 자유와 평화의 수호는 건전한 육체 건전한 정신을 [표방]하는 국제 체육인의 원만한 [연대]로 이루어질 수 있다는 것을 좌하는 것”이라고 표현하였다(Chosun Ilbo, 1955. 6. 15.).

사회적 주체로서 ‘체육인'이 수행해야 하는 '대중화' 의 책 무는, '건강한 신체와 건전한 정신'이라는 사명을 일반 대중 들의 생활무대 속으로 이식시키고 실천토록 하는 일종의 과 업으로 묘사된다. 예컨대, 해방 이후 첫 새해를 맞이한 1946년의 3월에, 조선체육회 회장 이병학은 조선일보에 “대중 본위로"라는 제목의 칼럼을 다음과 같이 기고하였다.

우리 체육인은 과거에 있어서 너무 지나치게 선수 본위 올림픽 지상 주의를 취하여왔으나, 이제부터는 체육의 대중화를 꾀하여 농촌 공 장 또는 사무원들에게까지 이를 보급 장려하여야 전국민의 심신양 방면을 통하여 꾸준히 연마하여 새 국가건설에 있어 영원히 번영할 수 있게 하는 책임을 절실히 느껴야 된다. 특히 근로 대중에게 유익 한 체육을 보급 장려함으로써 국민의 체위가 항상되고 생산들이 증 진되며 국방과 치안이 유지될 것이다(Chosun Ilbo, 1946. 3. 5c.).

또한, 조선일보는 아트레팀 구락부 회장 이인태가 기고 한 “지도자를 고대”라는 제목의 칼럼도 같이 수록했는데, 내 용인즉슨 "우리 체육인은 자아를 버리고 대중을 위하여 희 생하는 것처럼 고귀한 것은 없다"라고 강조하면서, "지금 우 리 체육계는 대선배로서의 지도자와 현역에서의 지도자를 기다리고 있다"라고 밝혔다(Chosun Ilbo, 1946. 3. 5d).

그렇다면, '체육인' 의 개념이 '건강한 신체와 건전한 정 신'의 모토를 대중과 교육적으로 접속, 교감, 안내하는 사회 적 주체로 서사화되는 핵심적인 '맥락' 은 무엇인가? 그것은 바로, 20 세기 중반 국제관계의 정치적 동학 속에서 한국 사 회의 ‘비전'과 '국민다움' 의 방향성을 사유하고 성찰하는 주 체 형성의 담론이 대두하게 된 지형 속에서 찾을 수 있다. 
$\operatorname{Kim}(2012)$ 이 논의하였듯이, 해방공간과 건국 초기의 시기 는 서구 문명의 우수성을 정당화하는 논리로 기능해온 문명 담론과 소위 '선진국 대 후진국'이라는 위계적 모델이 새롭 게 형성되고 있던 발전주의 담론이 혼재하면서 교차, 전환 되고 있던 시기였다.

이러한 주체 형성의 담론 속에서, '체육'은 문명국가와 선 진국의 문화적 상징을 의미하는 '기표'로 자주 등장하였지 만, 점차 그것이 내포하고 함의하는 '기의'는, '스포츠정신', '스포츠맨십', '운동 정신', '체육 정신'과 같은 도덕적 에토 스와 결합하기 시작하였다. 즉 한국 사회의 구성원들이 각 자의 삶과 생활 속에서 이식하고 실천해나가야 하는 일종의 국민적 도덕의식이자 윤리관의 메타포로 확장되기 시작한 것이다. 그리고 ‘체육인'의 개념 역시 그러한 이상적이고 바 람직한 성격의 국민 의식을 계발하여 직접 실천하고 모범을 보이는 국민적 역할모델의 사회적 주체로 사용, 이해, 소통 되었다.

특히 이러한 성격의 주체 형성의 서사는 한국 전쟁 이후 더욱 크게 이슈화된 체육계의 파벌 문제, 그리고 다양한 형 태로 우후죽순 터지기 시작한 불미스러운 사건들을 '이야기' 하는 국면 속에서 더욱 두드러졌다. 다시 말해, '체육계'에서 일어나는 불미스러운 사건들을 마주하고 비판적으로 직시하 는 성찰을 통해 ‘수치와 부끄러움' 의 집합적 감정을 공유하 여 교감하고, 나아가 새로운 민주사회의 주체로 활동하는 집 합적 정체성을 재인식하고 결속하는 '자부심과 긍지' 의 자기 -구호로 변환되는 것이 바로 '체육인'의 개념이다.

\section{신문 기사 속 ‘체육인'의 부정적 담론: ‘수치/부끄러움’을 집합적으로 성찰, 재결속하는 민족-국가적 주체}

‘체육인'의 개념이 특정한 사건 및 문제와 관련하여 집합 적 반성과 성찰의 주체로 등장하는 서사의 내용과 양상을 서 술하기에 앞서 한 가지 언급할 사항이 있다. 그것은 바로, '수치/부끄러움' 의 감정을 공유하면서 집합적 정체성을 재 인식/강화하는 패턴의 서사가 특정한 시기와 국면에 맞추어 갑자기 출현한 것이 아니라는 점이다. 간단히 말해, 그것은 '체육인'의 개념이 사용될 때부터 항상 존재하고 있었다. 대 표적 예로, 조선체육회 회장 이병학이 해방 이후 처음으로
맞는 새해인 1946년 정월 초에 체육 한국의 미래를 전망하 고 역설하는 내용으로 조선일보에 기고한 칼럼을 들 수 있겠 다. “건국 체육 이념”이라는 제목의 이 칼럼에는, '체육인' 의 이름으로 집합적 성찰과 반성의 코드가 흐르는 문맥을 다음 과 같이 발견할 수 있다.

체육이라 하면 $\cdots$. 곧 경기와 선수를 연상하게 되리만큼 체육은 전문 화되고 특수화되어 일반 국민의 생활과는 유리되어 있었다. 마치체 육은 그 자체가 사회의 분업인 것 같이 보였다. 즉 운동경기에 대하 여 특별한 취미와 소질을 가진 사람만이 소위 스포츠맨으로 뽑혀 체 육계에 종사함으로써 체육인은 한 특수한 사회군을 이루고 있었다.

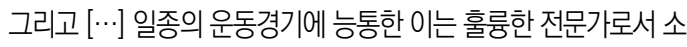
위 선수의 영예를 가지는 것이다. 이리하여 체육에 관계하고 체육에 친근한 사람은 그네들 선수뿐이라고 하는 결과로 되어 일반 세인은 부지불식 중 체육을 자기와는 인연이 먼 것으로서 으레 남의 일처럼 보게 된 것이다(Chosun Illbo, 1946. 1. 9),

그러나 체육이라는 것은 어디까지든지 민중 일상의 것이요 어느 특 수한 몇몇 사람의 전속물인 것은 아니다. [...] 체육에 있어서의 진보 적 민주주의적 건설은 [...] 체육의 일부 사회층에 의해 독점되고] 비생산적[인] 악적 경향을 가진 기형 발전 형태를 극복하고 일반 근 로 대중이 일상생활에 있어서 적극적으로 체육 운동에 참가하여 전 국민적 입장에서 체력의 향상 건강의 유지 발전 위생 사상과의 결부 육체의 균형적 발전을 가장 합리적으로 이행할 수 있는 체제를 확립 하는 것이다(Chosun Ilbo, 1946, 1. 10).

위의 인용문에서, 우리는 두 가지를 유추할 수 있다. 하나는, 체육의 실제가 전문화되고 특수화되면서 특정한 사회집단 군을 형성하게 되었지만, 대중 일반 사람들과는 유리된 성 격이 크다는 점, 그리고 다른 하나는 "일부 사회층에 의해 독점"되는 “기형[적] 발전 형태”를 띠고 있었다는 점이다.

2 개월 후, 조선일보는 체육 분야의 미래를 전망하는 주요 인사들의 글을 모아 수록했는데, 그들 중 하나인 당시 조선 축구협회 상무이사 김화집의 칼럼, "체육은 즉 교육" 속에 는, 해방 정국의 '체육계'를 비판적으로 진단하는 문제의식 을 좀 더 구체적으로 엿볼 수 있다.

해방 후에 소위 체육지도자들이 사상적 동요나 주의, 주장의 대립 항쟁 등으로서 모모 $[(\mathrm{OO})]$ 당에 참가하여 주접 행동을 계속하고 있 는 이도 있는 듯한데, 이러고서야 어찌 체육을 후배에게 인도할 수 있겠는가? 우리들 체육인은 교육자다. 우리의 목적은 사상도 물질 도 명예도 아닌 것은 상식이 되어 있다. 우리 체육인은 강력으로 다 
른 계급을 억누르고 권력에 대하여 복종이나 굴종하게 하는 정부의 쾌감을 갖는 것이 아니라, 희생적 도덕에 치중하여 심적 방면에 신 종의 관계를 맺는 대로 방향을 [추진]하여야 된다(Chosun Ilbo, 1946. 3. 5e.).

위의 인용문이 지적하는 것은, 일부 체육 관련 인사들이 정 치적이고 정파적인 활동을 일삼고 있는데, 그것은 ‘체육인' 으로서 추구할 바가 아니라는 일종의 훈계이다.

이렇듯, '체육인'의 개념은 '체육'과 관련된 부정적 의미 가 생산, 소통되는 맥락 속에서 자주 등장하는데, 그러한 서 사들은 주로 1) 부정적이고 바람직하지 못하며 불미스러운 사건과 행태 등을 들추어 고발하고, 2) 그러한 실태와 실상 이 개인의 문제가 아닌 '체육인' 전체의 ‘수치/부끄러움'을 사는 의미임을 환기한 다음, 3) '체육인'의 본분, 사명, 책무 등을 다시 강조하는 구조와 흐름으로 구성된다. 이러한 서 사 구조를 통해, ‘체육인' 의 개념은 ‘수치/부끄러움'의 집단 적 감정을 공유하고 다시금 집합적 정체성을 확인, 결속, (재)강화하는 자기-재현의 언어적 장치로 기능한다.

특히, ‘체육인'의 ‘수치/부끄러움'을 불러일으키는 원흥 으로 자주 제기된 사건, 현상, 행태 등은 주로 다음의 네 가지 패턴으로 분류할 수 있다. 그것들은 바로, 1) 개인 및 집단적 주체들 간의 분규, 알력, 파벌과 같은 분란, 2) 해외 원정과 관련된 비상식적이고 파렴치한 추태, 3) 구타 및 폭력과 같은 일상적 난동과 폭행 사태 등이다. 이하에서는, 필자들이 시 간적 순서를 고려하여 ‘체육인'의 개념이 등장하는 패턴과 기능 등을 정리하여 재구성하였다. 1948년 런던올림픽을 시 작으로, 대한체육회가 제 3 공화국의 출범 아래 새로운 시작 의 전기를 마련한 1961년 9월까지의 시기를 다루고 있다.

먼저, 1948 년 런던올림픽의 경우, 두 가지 쟁점이 주요 화두로 떠올랐다. 하나는, 마라톤선수들이 참패한 원인이 선수 및 코치들 사이의 분규와 불화 때문이었다는 의혹이 며, 다른 하나는 올림픽 후원권의 발행으로 마련되어 지급 된 선수단 지원 명목의 국민 성금의 지출을 둘러싼 논란이었 다. 예컨대, 경향신문은 “올림픽 패인의 구명”이라는 제목의 장문의 칼럼을 세 차례로 나누어 게재했는데, "합심하지 못 한 것이 화근, 사리사욕에 움직인 선수”라는 부제 속에 그 대답이 들어있다. 칼럼의 내용은, 시합 전 연습 기간 중의 합 숙 생활에서부터 불화가 시작되었고, 지도자들도 둘로 나뉘 어 합심을 도모하지 않았으며, 실제 경기에서까지도 선수들 은 개인행동으로 경기에 임했다는 것이다. 이 점들을 조목
조목 따진 뒤, 칼럼은 다시 다음과 같이 토로하고 있다.

이 상태에 비추어 어찌 우승을 바랄까보나? 집안에서 새는 바가지 가 들에 가서도 샌다는 격언도 있거니와 이 격언이 바로 우리 선수 단을 두고 말한 것 같기도 하다. 설사 국내에서 선수끼리와 감독 사 이 또는 선수와 선수 감독진은 감독진대로 불화하였다 하더라도 이 네들이 개인의 영예도 영예지만 삼천만 겨레의 명예와 조국의 영광 을 위하여서는 과거의 모든 불화 없이 서로 악수하고 합심하여 외적 에 당함이 마땅하거든 외국에 가서까지도 알력과 불화를 그대로 발 로시켜 조국의 영예는 고사하고 오점을 남겨두게 한 책임자는 과연 누구일까? [...] 결승점을 앞두고 운동장에서 기진맥진하여 그만그 자리에 쓰러져 들것에 태워 병원으로 간 벨기에 용사의 자기 조국을 위한 최후 일순까지 분전한 거룩하고도 눈물겨운 스포츠맨의 행동 이 있[는] 반면에[,] 자기의 사리사욕으로 인하여 참패한 우리 선수 가 있다는 것은 이 무슨 명예롭지 못한 일이나?(Kyunghyang Shinmun, 1948. 8. 20.)

풀이하자면, 마라톤 참패의 원인은 선수 및 지도자들 사이 의 "알력과 불화"에 기인한 것이며, 우리의 선수들이 경기에 서 보여준 “개인행동”들은 “스포츠맨의 행동” 과 대치되는 “오점”이자 곧 “명예롭지 못한 일”이라는 것이다.

한편, 동아일보는 올림픽 후원권으로 마련된 성금 지출 에 대한 의혹을 제기했다. "해방 조국의 이름을 해외에 널리 알려 체육 한국을 통하여 세계 각국과의 친선과 우위를 두텁 게” 하기 위해 “우리 민족의 남녀노소가 너나 할 것 없이 주 머니를 떨어 [...] 올림픽 후원권을 서로 권유하면서 샀던 것”임을 환기하면서, 다음과 같이 쓴소리를 했다.

\section{그네들이 일단 고국에 돌아오면 마땅히 일반 민중에게 올림픽대회 에서 활동하던 경과를 보고하며 대회의 경비는 얼마나 썼다는 것도 보고하여야 옳음에도 불구하고, [...] 6개월이 지난 오늘날까지 하 등의 보고가 없다는 것은 규율과 예의를 굳게 지키는 체육인이 취할 행동이 아니다(Dong-A llbo, 1949. 3. 13.).}

위의 인용문이 시사하듯, 전 국민의 기대와 헌신 그리고 애정 을 담아 마련한 거대한 후원금에 대한 정확한 지출내용과 경 과를 공개하는 것이 곧 “규율”에도 어긋나지 않고 “예의"에도 부합하는 이른바 “체육인이 취할 행동”이라는 의미이다.

런던올림픽 선수단과 관련된 불미스러운 사건은 선수단 이 귀국하는 상황에서도 불거졌다. 경항신문은 귀국 환영 행사에 참석한 한 주요 인사의 칼럼을 전하고 있는데, 요지 인즉슨, 세관 검사에서 “수입 금지품”을 잔뜩 담은 여행 가 
방으로 조사를 받은 “스포츠 사절” 답지 못하고 “뻔뻔스러운 임원선수”들이 있었으며, 환영회장에서는 한 임원과 선수 사이에 “돈의 대차 문제”로 기인한 난투극의 “추태”도 있어 “비열과 증오”가 “용솟음”쳤다는 내용이다(Kyunghyang Shinmun, 1949. 4. 16).

1948 년 런던올림픽을 둘러싼 의혹과 비판은 이듬해인 1949년 제53회 보스턴세계마라톤대회의 선수파견 문제, 일명 '김포공항 난투극' 논란으로 이어지면서 더욱 증폭되 었다. 사건의 경위를 간략히 요약하자면 이렇다. 원래의 계 획은 4 월 19 일 미국의 보스턴에서 개최되는 대회의 일정을 고려하여, 선수 3 명과 감독 및 인솔 3명으로 구성된 총 6명 의 선수단을 2월 6일에 파견하기로 했었다. 그러나 "여비 문 제와 선수단 간부 선정의 문제로 옥신각신”하여 3월 21일과 28일 그리고 4월 4일까지 미루어지다가 급기야는 4월 11 일까지 연기를 거듭하게 된 것이다. 이 와중에 몇몇 구성원 들이 출전을 고사하면서, 문제가 다시 일어나는 듯했으나, 이어진 일련의 합의 속에서 결국 출국일이 11 일로 추진되었 다. 그러나 정작 출국 당일, 또다시 파견단 인원과 선정 문제 로 김포공항에서 서로 주먹을 치고받으며 유혈이 낭자하는 난투극이 일어난 것이다. 그 와중에 선수단은 다시 둘로 갈 려, 일부는 서울로 돌아가고, 또 다른 일부는 비행기를 타고 출국하는 촌극이 펼쳐졌다.

결국, 이 사건은 이승만 대통령까지 개입하게 되는 지경 까지 연출되었는데, 동아일보에서 전한 대통령 담화의 내용 은 다음과 같다.

국제운동경기대회에 선수를 파송하는 것은 국권 회복에 대한 중대 한 조건이다. 그러나 불행이 운동단체와 선수 중에 부분적 투쟁이 있어 국제상 수치로운 추태를 발로하게 된 것이 몇 번 있었고 또 따 라서서로 불합작하는 중에 경비문제에 장애가 되어 매앙 곤란한 경 우로 지내게 되니 이것을 방임하고는 아무리 기술이 충분한 선수를 가지고라도 국제상 자랑할 수 없이 될 것이다. 금번 보스턴 마라톤 선수 일행에는 창피한 행동은 용서하기 어려운 경우에 달하고 있으 므로 지금부터는 국제운동경기에 파송하는 모든 공작은 일체 정지 하고 원만한 조직과 경제 준비를 충분히 마련하기까지는 아무도 파 송치 않을 작정이니 이 문제에 중대한 책임을 지고 깊이 관심하는 모든 지도자들은 속히 회합해서 [...] 완전히 해결하기를 부탁하는 바이다(Dong-A llbo, 1949. 4. 13.).

이렇듯, 대통령의 전면 출전 금지 조치로, 일본에서 머물고 있 던 일부 선수단 인원이 다시 귀국함으로써 사건은 일단락되었
다. 이리하여, 1949년 제53회 보스턴 마라톤대회는 한국 마 라톤의 역사 속에서 비어 있는 한 페이지로 남게 되었다.

사건이 수면 위로 공개되면서, 언론들은 일제히 건국 초 기의 무책임한 '체육인'과 '체육계'를 질타하는 쓴소리들을 쏟아냈다. 구체적으로, 동아일보는 “보스턴마라톤 파견에 추태, 김포공항서 유혈극, 체육계 정화가 시급”이라는 제목 으로, 그리고 조선일보는 "분규를 거듭하는 체육계, 출발 직 전에 난투극, 보스턴대회 출장문제로”라는 헤드라인으로 사 건의 전말과 심각성을 상세하게 보도했다(Chosun Ilbo, 1949. 4. 13; Dong-A Ilbo, 1949. 4. 13.). 여기서 잠시, 조 선일보의 칼럼이 전하는 사태의 심각성과 어조를 들어보자.

\begin{abstract}
돌이켜보건대 국내의 각종 운동경기에서는 거의 대회 때마다 신성 한 운동경기장에 뛰어들어가 상대편 선수와 또는 심판을 구타하는 등 불상사가 접종하였고, 또 해외 원정에 있어서는 그 역원 및 선수 선발 문제로 갖은 모략과중상을 일삼았고, 강직을 자랑하는 체육인 으로서는 도저히상상치도 못할 분규를 야기하여 마음 있는 자로 하 여금 모골을 서늘케 한바 적치 않아 순결 강력한 체육계의 재편과 뭇 체육인들의 맹성을 촉구하여왔던바 이번 또 다시 보스턴 마라톤 선수 파견을 에워싸고 출발 직전 비행장에서 일대 난투극을 연출하 고 선수 일부는 출발하고 일부는 대회 참가를 포기하는 등 불상사를 야기하여, 일반의 비난은 물론 금후 해외원정은 일체 중지한다는 이 대통령의 별항과 같은 담화까지 발표하기에 이르렸다(Chosun Illbo, 1949. 4. 13.).
\end{abstract}

위의 인용문을 통해 알 수 있듯이, ‘체육인’ 의 개념은 김포공 항의 난투극을 통해, 모골을 서늘케 하고 상상도 못 할 그런 '수치/부끄러움' 의 감정을 느끼고 공유하는 집합적 주체로 제시된다. 그러나 다른 한편으로 다시 강조되고 있는 것은 ‘체육인’의 (긍정적인) 집합적 정체성을 확인하고 회복하는 과정이다. 다시 말해, “신성한 운동경기장”에서 “모략”과 "중상” 없이 국가를 위해 최선을 다하는 "순결”하고 "강직" 한 주체가 바로 '체육인'이다.

경향신문 역시 “부패된 체육계의 이면”이라는 제목의 장 문의 칼럼을 3 회에 걸쳐 연재했다. 칼럼은 이 사건이 "불상 사"의 차원을 넘어 “세계적인 수치”를 사게 되면서 “한국의 체육계”가 “일대 위기에 직면하고 있”음을 강조했다. 구체 적으로, 경향신문은 이 사건이 "결코 우연한 사실이 아니며 돌발적인 사고도 아닌 곪을 대로 곪은” 일이라는 점을 강조 하면서, 과거에서부터 지속하고 있는 ‘체육계' 의 “부패”를 조목조목 지적하고 있다. 요컨대, 해방 이후 "좌우익의 정치 
이념이 침투되어 조선체육회는 체육회대로 그 산하단체인 각 협회 연맹은 제각기 분열과 투쟁”을 계속해왔으며, 그것 이 곧 “런던올림픽 출전 [관련] 체육계의 암투”로 이어졌고, 다시 보스턴마라톤대회 출전 문제로 폭발되었다는 것이다. 이러한 진단을 통해 칼럼니스트는 "귀여운 자식 동생 종아 리 때려 잘 되라는 격”의 비유를 들고, “썪어진 우리 체육계" 에 대한 쓴소리임을 밝히며 다음과 같이 마무리한다.

알력과 유혈 그리고 모함에 엉키어 지금 장도라고 할만한 항로 도중 에서 정부의 명령으로 [되] 돌아오는 김혁진 감독과 최윤칠 선수 등 의 수치야말로 이로 형용할 수 없거니와 이렇게까지 부패할 대로 부 패한 우리 체육계는 세계 어느 곳에서도 그 유를 보지 못할 것이다. 신성하고 건전하여야 할 운동계에서 이러한 부끄러움을 국제적으 로 폭로되지 아니하면 안 되게 한 그 배후의 조종자와 흑막은 누구 이며 또 어떻게 될 것인가? [...] 필자는 그들이 그동안 어떠한 모략 과 시의심에서 나온 추행을 거듭하여 이러한 유혈의 싸움을 벌려놓 을 때까지의 경위는 너무나 표현하기가 부끄러워 그 폭로를 삼가서 한국 체육계의 체면을 더 이상 [손상시키고 싶지 않다 (Kyunghyang Shinmun, 1949. 4. 18.).

이처럼, '체육인’의 개념은 ‘체육계'와 함께 집합적 수치의 감정을 공유하고 아울러 (긍정적인) 집합적 정체성을 다시 환기하는 메시지의 서사적 주체로 등장한다.

이러한 패턴의 서사는 한국 전쟁 이후에도 계속 등장한다. 1952년 헬싱키올림픽 선수파견 문제로 대한체육회와 대한 올림픽위원회가 서로 갈등을 겪는 사건이 논란이 되었는데, 조선일보의 한 사설은 다음과 같이 신랄하게 비판하고 있다.

올림픽 선수파견에 제하여 체육회 내에 분파적 다툼이 있음은 묵과 할 수 없다고 정부 대변인이 경고, 만일 사실로 이런 다툼이 있다면 이런 체육인은 사이비 체육인이라할 밖에, 전번 런던 올림픽대회 때 의 전철을 되풀이 하려한다면 그야말로 건망증 체육인이 아닐까? 운동의 참된 정신은 페어플레이에 있는 것, 좀 더 단순하고 겸허하 고 솔직할 수는 없는가(Chosun Ilbo, 1952. 5. 8.)?

흥미롭게도, 이 사설은 ‘체육인’의 개념을 “사이비 체육 인” 그리고 “건망증 체육인”과 대조시키고 있다. 쉽게 말해, ‘체육인’은 “단순”, “겸허”, “솔직”한 “페어플레이”를 하는 주체이고, ‘사이비/건망증 체육인' 은 파벌로 나뉘어 싸움을 일삼는 주체들이다.

1956년 제16회 멜버른 올림픽대회에서도 선수단 파견 문제로 인한 비판의 목소리들이 언론사들로부터 쏟아져 나
왔다. 경향신문의 한 칼럼은 "국민은 다량 파견을 원치 않는 다!”라는 첫 문장과 함께, “체육계에 인망이 부족한 사람이 혹은 무능한 사람이 [임원] 진에 끼었느니 또는 승산도 없는 선수들을 왜 보내느니 하는 비난 소리를 듣게 되니 체육인의 한 사람으로 이를 들을 적마다 불쾌하기 짝이 없다”라는 쓴 소리와 토로를 함께 실었다(Kyunghyang Shinmun, 1956. 10. 17). 동아일보도 “오륜선수단 선정 시비”라는 제 목의 기사를 통해, 선수단 구성이 "체육인들의 진실한 의사 를 반영시킨 것”이 아님은 물론, 선수단의 올림픽행을 “유 람"과 “견학”에 비유하면서 “참패의 역사를 한국체육사에 영구히 기록하려는 망동”이라고 비판했다(Dong-A Ilbo, 1956. 10. 23). 동아일보의 또 다른 칼럼은 훨씬 신랄한 목 소리를 다음과 같이 전하고 있다.

체육은 신성하다고 하여 우리도 그렇게 명심하고 있다. 그러나우리 나라 체육계를 볼 때 한심한 생각이 아니 날 수 없다. 신성의 두 글자 에 숨어서 그 썩어빠진 정치와 협잡 몰이 행위가 감행되고 있다. 외 국 원정을 가게 되면 그것을 기회로 삼아 돈벌이 가는 체육인이 되 고 말았다. 그나마도 정치성을 띠지 않으면 원정의 생각조차 못 할 정도니 이것 참말 울면서 겨자 먹는 격이다. 금번 올림픽대회 파견 문제만 하여도 이 무슨 부꾜럽고 쑥스러운 짓인가? 국민 전체에 얼 굴을 들 염치가 없으며 깨끗이 기권이라도 하고 싶은 마음까지도 든 다. 관계 인사들은 우리 체육인들을 상품화하지 말라! 시골 잔치 집 찾아가는 거지처럼 어중이떠중이 따라오지 말라. 제발 역원이니 하 고 따라와서 엉뚱한 사업만 하고 돌아와서는 제일 생색을 내는 그따 위 행동은 삼가달라(Dong-A llbo, 1956. 10. 31.).

수치와 부끄러움의 서사는 비단 올림픽을 비롯한 국제대 회의 선수파견에 관한 쟁점뿐 아니라, 국내의 스포츠 일상 에서도 한결같이 등장하고 있다. 여기에는 특정한 패턴이 있는데, 주로 전국체육대회와 같은 대규모 행사를 기획, 준 비, 운영하는 데 있어 몰상식적인 수준의 작태를 드러내거 나, 경기장 폭력과 난동의 추태 등이 ‘체육인'의 수치와 부끄 러움을 일으키는 행태들이었다.

몇몇 기사들의 내용을 추려서 소개하면 다음과 같다. 먼 저, 1952년 전란의 와중에도 뜻깊게 개최된 제 33 회 전국체 육대회에서는 무성의한 대회 운영과 예산 및 경비 사용의 문 제 그리고 수차례의 폭력 사건과 난투극이 일어났다. 이에, 조선일보는 “찾을 길 없는 체육정신"이라는 제목 아래, "대 한체육사에 오점을 남긴 것” 은 물론, “전 체육인들의 굴욕이 요 대한의 수치”라고 표현하고 있다(Chosun Ilbo, 1952. 
10. 26). 1953년에는 미국 빅토리 농구단 초청 문제로 인한 대한체육회와 농구협회의 마찰, 아시아올림픽 육상 선수 선 발 경기의 무단 연기, 국가대표 축구팀의 동남아 원정 경비 의 부정 소비 등의 논란들이 불거졌는데, 동아일보는 이러 한 불미스러운 일들로 인해 “도저히 체육인으로서의 면목을 세울 수 없어 사퇴하겠다는 [체육회] 간부들[이] 상당수에 달하고 있”으며, “차라리 대회 원정대회를 당분간 폐기하고 [...] 국내에서 기술 연마[에] 치중하는 것이 타당하”다는 주 장까지 있음을 보도하였다(Dong-A Ilbo, 1953. 9. 9).

또한, 전국체육대회의 경우, 경기장 폭력 사태에 관한 기 사들이 해마다 줄지어 보도되었다. 몇몇 예를 들어보자면, 1952년, 동아일보는 “반목갈등의 체육계"라는 제목 아래, 제33회 전국체육대회 행사의 준비와 운영 속에서 일어난 “체육회 간부들 간의 갈등”과 “알력" 그리고 “경기 진행에서 의 추태” 등을 보도하였으며(Dong-A Ilbo, 1952. 11. 10), 경향신문도 1958년 제39회 대회에 일어난 다양한 불상사들 을 소개하면서, “사고속출의 엉망 진탕의 대회”이자 “민족적 인 수치”에 대해 “한국체육계가 자가숙청”하는 마음으로 “모 든 체육인은 깊은 자가반성이 있어야 할 것”이라고 비판하는 메시지를 담았다(Kyunghyang Shinmun, 1958. 10. 10).

한편, '체육인' 의 개념이 수치와 부끄러움의 서사 속에 등 장하는 것은 특정한 사건이나 문제를 다루는 단발적 보도에 서만 볼 수 있는 것이 아니다. 예컨대, 경향신문은 체육회의 사업비를 후생비로 마구 쓰는 체육인들을 "팔자 좋은 양반 들”이라고 비유하며 “수입 없는 지출”만 존재하는 행태를 “체육계의 불가사의”라고 비꼼과 동시에(Kyunghyang Shinmun, 1958. 12. 10), “체육인의 미덕”이 사라져가는 차원을 넘어 “사회 물의의 대상이 된 것”을 한탄하면서, "체 육인들이 이래서야”라는 비난이 없어지는 것이 “소원”이라 는 칼럼을 내놓기도 하였다(Kyunghyang Shinmun, 1958. 12. 12). 이렇듯, 체육인들과 연관된 불미스러운 문 제와 부정적인 행태는 일상적이었음을 알 수 있다.

특히, 수치와 부끄러움의 서사는 한 해를 정리하거나 새 해의 새로운 출발을 알리는 맥락에서 자주 등장하였다. 경 향신문은 1952년 한해를 정리하는 “체육 편"의 코너에서, "깨끗해야 할 스포츠맨십을 완전히 땅에 떨어뜨린 해였고 떨어진 스포츠맨십을 또다시 짓밟고 비비고 한 해"였음을 강조하며 “내분과 허식의 일년”으로 평가하였다 (Kyunghyang Shinmun, 1952. 12. 26). 또한, 1955년의 마지막 날, 경향신문은 멜버른 올림픽에 대한 전망을 담아
“병신[년] 체육에의 제언"을 내놓았는데, "가장 불안을 느끼 고 초조감을 가지게 되는 것은 [...] 내분과 알력을 거듭하고 있는 체육계의 혼란”이라고 언급하면서 다음과 같이 총체적 진단과 비판을 가했다.

근본적인 원인을 따진다면 진정한 체육 이념을 몰각한 분자들이 정 치적 사회적 세력을 체육에다 끌어넣어서그 배경을 미끼삼아자신 의 출세를 꾀하고 날뛰는데서 유발되어지고 있는 것이다. [...] 그러 나 이것이 일단 정치의 도구로 그릇 지도되거나 또는 비체육적이고 어떠한 불순성이 개입될 때에는 맑고 아름다운 것이 될 수 없는 동 시에 진정한 체육의 효과를 가져올 수 없게 되는 것이다. 그래서 우 리는 항상 아마추어리즘을 절규하고 체육의 순수성을 주장하여왔 다. 그러나 오늘날 한국의 체육 단체의 대표자의 명단을 보라. 우리 가 알고 있는 한에 있어서 체육 운동의 문외한인 사람들이 해괴하게 도 체육을 영도하는 자리에 있지 않는가? 그러면 한국체육이 무엇 때문에 정객이나 재벌이나 권세가를 스스로 나아가서 받들게 되며 그들의 세력을 방패로 삼아야만 하는가? 바로 여기에 한국체육의 병폐가 있으며 암이 되었다고 생각한다. 또 그러면 왜 체육 문제를 체육인 자신만으로써 해결 짓지 못하며 동지적인 이념에서 단합이 되지 못하는가? 바로 이 때문에 혼란이 내포되며 체육의 이데올로 기적 해이가 잠재해 있는 것이다(Kyunghyang Shinmun, 1955. 12. 31).

동아일보도 건국 및 창립 10 주년을 맞이한 1958 년에 “건국 10 년의 체육계"라는 칼럼을 통해 "화려한 것처럼 보 이는 체육계의 10 년사 뒤에도 추악한 트러블도 적지 않았” 음을 다음과 같이 보도하였다.

보스턴 마라톤 행에 앞선 김포비행장에서의 난투를 필두로 런던올 림픽 파견 전의 분열이며 각종 대회마다 예외 없던 분쟁과 모략 중 상이 빛나는 체육사를 더럽혔고 차곡차곡 쌓은 금자탑에 균열을 가 져왔던 것이다. 이는 독선과 유치한 공명심, 졸렬한 파세에서 오는 추태요, 진정한 체육정신에 투철지 못한 사이비체육배가 빚어낸결 과이다(Dong-A llbo, 1958. 8. 13).

수치와 부끄러움의 감정을 집합적으로 공유하는 '체육 인' 개념의 서사는 건국 및 체육회 창립 10 년 이후에도 계속 등장하고 있는데, 특히 대한체육회의 임원 구성을 둘러싼 문제로 크게 분출되었다.

이른바 '대한체육회 분규'라는 이름으로 회자된 사건의 내용은 이렇다. 1959년 1월 19일과 20일, 대한체육회는 정 기 전국평의원회를 열고 새로운 집행부를 선임하였는데, 이 
기붕 회장이 평의원 직후 사의를 표명하고 건강상의 이유로 칩거를 시작하였다. 이에 신임집행부는 이 회장의 사의를 만류하고 재가를 받는 노력을 수차례 시도하였으나, 별다른 성과 없이 수개월 동안 임원진의 공백 상태만 지속하게 되었 다. 2년 전 1957년 총회에서도 이 회장이 사의를 표명했다 가 다시 임시총회를 열고 새로운 임원을 추가로 선임하고 사 의를 철회한 적이 있었기 때문에, 이번 사건에 대한 처리와 해결 역시 새로운 신임집행부를 계속 유지할 것인지, 새로 운 회장단을 추대할 것인지, 회장의 사의를 만류하고 다시 새로운 신임집행부를 꾸릴 것인지 등의 문제들을 둘러싸고 다양한 말들이 오고 갔다.

언론들은 일제히 체육회의 공백을 지적하고 분규를 비판 하는 목소리들을 쏟아냈다. 그러한 내러티브들 속에서 '체육 인' 의 개념은 크게 두 가지 양상으로 '주체화' 되는 패턴을 드 러내는데, 하나는 파벌과 암투로 얼룩진 수치와 부끄러움을 집합적으로 공유하는 주체, 그리고 다른 하나는 그러한 감정 의 공감을 통해 다시 체육의 순수성을 자각하고 환기하는 주 체이다. 몇몇 구체적인 대목들을 나열하자면 다음과 같다.

먼저 조선일보는 “스포츠 진흥과 체육회 파쟁”이라는 제 목의 칼럼을 통해, “너무나 뿌리 깊은 체육회의 파벌”을 지 적하며, "체육인들 간에 암투가 계속되는 한 누가 집행 진에 들어가 있든 간에 반드시 반대파가 있어 [...] 비난을 일삼는 사람이" 있을 것이라고 지적했다(Chosun Ilbo, 1959. 4. 30). 동아일보의 한 칼럼은 "대한체육회 이사진 개선이 있 을 때 2년마다 거듭되는 불행”임을 강조하면서, “정치와 문 화를 분리하지 못하고 혼돈하여 권력과 금력을 배경으로 하 는 정치가 장구히 지속되”어 일어난 “부패”라는 점을 피력 했다(Dong-A Ilbo, 1959. 4. 11), 경향신문도 "대한체육 회의 분규와 그 해결” 이라는 칼럼을 게재했는데, “체육회가 순수한 체육인만의 집합체로 되어야 할 것임은 너무나 자명 하[며] 체육계에까지 정치성이 개입되는 것은 배격되어야 한다"고 주장했다(Kyunghyang Shinmun, 1959. 4. 4).

체육인들의 분규와 체육계의 혼란은 수습될 겨를도 없이 1960 년 $4 \cdot 19$ 이후 이승만 정권의 퇴진과 맞물리면서 한층 더 심각해졌다. 조선일보에 의하면, 이기붕 회장과 신도환 부회장의 자연 사임으로 야기된 "체육계의 혼란기를 이용하 여 체육인들은 제각기 대한체육회를 위하여 일해보겠다고 (상무 이사 자리를 말함) 날뛰고들 있는가 하면 벌써 모모 인 사들은 제각기 회장단에 추대한다고 들먹거리고 있는 실정” 이었다고 하였다(Chosun Ilbo, 1960. 5. 1). 또한, 경향신
문은 신임 이사진을 선정하는 대한체육회 임시평의원회에 "도합 37명이란 대한체육회 유사 이래 처음 보는 가장 많은 이사 숫자를 정”한 것을 두고, "이와 같이 많은 수의 이사를 두기로 한 이날의 총회를 '감투의 분배'를 한 회합이라고 비 난”했다(Kyunghyang Shinmun, 1960. 6. 22).

이러한 상황에서, 언론들은 체육인들의 성찰과 체육계의 혁신을 요구하는 목소리들을 내놓았다. 예컨대, 경향신문은 “국내 체육계 정비가 최대의 끽긴 과제”이며(Kyunghyang Shinmun, 1960. 6. 24), 아울러 "참다운 한국체육 재건의 전기”를 마련해야 한다고 주장했다(Kyunghyang Shinmun, 1960. 9. 11). 조선일보는 "체육계의 정화를" 위해(Chosun Ilbo, 1960. 5. 4), "전국체육지도자들의 반 성”을 촉구했다(Chosun Ilbo, 1960. 9. 11). 동아일보도 1960 년 제 17 회 로마올림픽의 “참패”와 체육계의 문제점을 연관 지으면서 "기성 체육인들은 맹성하라"고 일갈했다 (Dong-A Ilbo, 1960. 9. 14),

이러한 내러티브들은 주로 다음의 세 가지 아이디어들이 결합하는 구조의 패턴을 띠고 있다. 먼저, 체육인들의 파벌 과 종파성의 추태를 설명하고, 이어서 이러한 문제점이 '체 육 정신’이나 ‘운동 정신'과는 거리가 먼 ‘체육인'답지 못한 것임을 강조하며, 아울러 그동안 체육인들과 체육계가 정치 와 깊숙이 연관되어 왔기 때문임을 확인함과 동시에, 이를 타개하기 위해서 무엇보다 체육의 비정치성과 순수성을 회 복하는, 즉 체육인 본연의 모습과 자세로 되돌아갈 것을 주 장하는 내용이다. 이러한 패턴을 잘 보여주는 한 예로, 조선 일보가 “체육계의 정화를” 이란 제목으로 보도한 한 칼럼의 내용을 발췌하면 다음과 같다.

운동 정신을 들고 나서는 체육부문의 활동이야말로 가장 순수하고 모범적이어야 했을 것이다. [...] 지금까지 체육계에는 분규와 알력 이 거의 연속적으로 일어나서 세상의 빈축을 샀던 것이다. 그리고 그러한 분규의 원인은 [...] 헤게모니 쟁탈을 위한 것이었고, 그 배후 에는 반드시 큼직한 모종의 정치적 세력이 작용하고 있었던 것이다. [...] 일부 체육인들은 직업적으로 권력과 세력에 아부하여 그 그늘 밑에서 체육이라는 탈바가지를 쓰고 체육계를 함부로 농단하여 왔 던 것이다. 결국 이러한 사이비적 무리 때문에 체육계는 그 활동이 마비되고 침체된 가운데서 체육인들 간에도 반목질시와 대립의 혼 란은 그칠 사이가 없었던 것이다. [...] 끝으로 한마디 말해두고자 하 는 것은 체육인들 간에 뿌리박고 있는 종파심을 버리라는 것이다. [...] 체육인이 합심해도 어려울 것인데 거기다가 출신을 따지고 고 향을 운위해서 독선과 배타를 일삼는다는 것은 용납될 수 없는 행동 
이라 할 수밖에 없는 일이다. 이제야말로 과거의 모든 부식과 과오 를 께끗이 청산하고 서로 반성하며 격려해서 체육계를 정화하는 길 로 온갖 노력을 경주할 것을 동지들에게 호소하여 마지 않는다 (Chosun llbo, 1960. 5. 4).

체육계의 정화가 필요하다는 주장은 제3 공화국이 출범 하는 과정에서도 등장하였다. $5 \cdot 16$ 이후 한 달이 지난 1961 년 6월 16 일, 새롭게 임명된 문희석 문교부 장관은 60 여 명 의 체육 단체 대표자 및 체육지도자들과의 회의에서 5 가지 요망사항을 발표했는데, 구체적인 내용은 다음과 같다. 첫 째, "경기의 승패뿐만이 아니라 스포츠맨십을 길러 내야겠 다." 둘째, "국민 반공 태세를 완비하기 위한 기초가 되는 국 민의 체력을 향상시켜야겠다." 셋째, "몸과 정신을 튼튼히 하 여 인간개조를 이룩해야겠다." 넷째, "국제경기는 관광 사업 적인 역할이 되어서는 안 되겠으며 선수단 선발에 있어서도 정치적 개입을 막아야겠다." 다섯째, "체육 단체 혁신을 위해 서는 체육인이 주동이 되어야 하며 어떤 정치적 요소도 제거 해야겠다"는 내용이었다(Chosun Ilbo, 1961. 6. 16).

경향신문은 이 소식을 전하면서 "국민 체위향상과 체육 발전책”이라는 제목의 칼럼을 통해, “모든 부정과 구악을 일 소하려는 $5 \cdot 16$ 혁명은 당연히 체육과 체육단체의 정화에 착수하지 않으면 안되었던 것”이라고 전하며 다음과 같이 ‘체육인'들에 대한 당부를 전하고 있다.

과거 일부 체육인은 스포츠맨십을 망각하였다. 그들은 건전한 체육 정신을 저버리고 승부에 집착하여 갖은 불상사까지 야기시켰으며 때로는 체력과 폭력을 혼동하는가 하면 심지어는 체육단체를 이권 획득의 수단으로 삼아왔다. 또한 체육단체 간에는 유기적 연락과 친 목이 결여되고 그들은 분규와 대립을 일삼았다. 이러한 것들은 체육 본연의 의의에서 볼 때 단불용[대]한 일이며 앞으로는 그러한 구악 이 완전히 불식되어야 할 것이다. 우리는 체육의 본령이 승부나 기 록에 있는 것이 아니고 건전한 국민정신의 배양에 있다는 것과 체육 이 특정인이나 특정 단체의 독점물이 아니고 국민 전체의 문제라는 것을 재인식해야 할 것이다. 그리고 건전한 심신으로 과거의 패배의 식을 극복하고 퇴폐주의를 일소하여 우리의 국시이며 혁명 제일 공 약인 반공투쟁에서 승리하는 힘을 길러내야 할 것이다. 끝으로 우리 는 체육의 발전이 국민의 사기에 미치는 영향이 지대하다는 것과 국 위의 선양에 있어서 체육이 얼마나 큰 역할을 담당하느냐 하는 것을 상기하여 앞으로 정부 당국은 당국대로, 체육인은 체육인대로 강력 하고 참신한 방책을 수립하기를 거듭 바라마지 않는다 (Kyunghyang Shinmun, 1961. 6. 17).
얼마 되지 않아, 체육계의 정화를 향한 열망은 새로운 전 환점을 맞이했다. 대한체육회는 그동안의 긴 리더십의 공백 을 깨고, $5 \cdot 16$ 이후 4 개월 만에 처음으로 새로운 회장을 맞 이했다. 1961년 9월 15일, 김동하 회장은 취임사에서 첫째, “체육회는 앞으로 양심적이고 근실한 체육인으로 단결”할 것이며, 둘째, "세계적 선수를 양성하여 대외적으로 국위를 선양”하고, 셋째, "대내적으로 국민 전체의 체육 향상을 목표 로 하"며, 넷째, "단시일 내로 종합 실내경기장을 시설하겠 다”라는 취임 포부를 밝혔다(Chosun Ilbo, 1961. 9. 16).

\section{결 론}

지금까지, ‘체육인'의 개념이 해방공간과 건국 초기의 시 대적 배경 속에서 본격적으로 등장하여 소통되면서 사회적 대표성을 얻어간 언어적 양상과 맥락에 대해 살펴보았다.

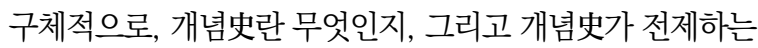
'개념'의 의미에 관해 설명하였으며, 이어서 왜 체육인의 개 념을 개념史의 접근과 관점에서 분석, 해석할 필요가 있는 지의 문제의식을 피력하였으며, 아울러, '체육인'의 개념을 해석하는 관점과 방법도 소개했다. 이러한 이론적 관점과 배경에 이어, 신문 칼럼에서 보이는 '체육인' 의 담론을 크게 두 유형으로 구분하여 서술했다. 하나는, 긍정적인 담론으 로, '자부심/긍지'의 감정을 집합적으로 공유하는 양상의 내 용과 성격, 그리고 다른 하나는, 부정적 담론으로, '수치/부 끄러움'을 통한 성찰을 통해 집합적 정체성을 회복하고 재 확인하는 양상의 내용과 성격을 정리하였다.

요컨대, 언어적 구성물로서의 ‘체육인' 개념은 체육이 관 계하고 있는 사회적 실재와 서로 영향을 주고받는 이중적 관 계의 상호작용 속에서 탄생한 언어이다. 한편으로, 그것은 일제 강점기 시절의 체육 전통을 이어나가고 건국의 흐름에 부합하는 발전의 이식을 동시에 추진하던 시기에, 새로운 민족적-국가적 주체의 체육적 표상을 발명하여 공유한 자기 -재현의 언어이다. 그리고 다른 한편으로는, 불미스러운 사 건들에 대한 수치와 부끄러움의 감정을 함께 반성하고 성찰 하는 의식을 통해 (긍정적인) 집합적 정체성을 다시 회복하 고 재확인하는 역할을 하는 정치적 언어이다.

끝으로, 이 연구를 마무리하면서 두 가지 사항을 제언하 고자 한다. 첫째, 필자들은 우리의 연구가 ‘체육인' 개념에 대한 다양한 공시적 분석과 통시적 분석을 끌어내는 것뿐만 


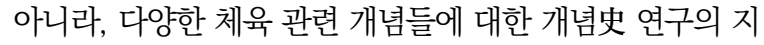
형을 형성하는 조그만 계기가 되었으면 하는 바램이다. 무 릇, 인간의 (스포츠) 역사 속에는 항상 변하지 않고 그대로인 것들도 존재하고, 또 늘 변하기 마련인 것들도 있다. 따라서 (스포츠) 역사연구 중에는, (스포츠) 역사 속에 존재하는 고 정불변하는 것들을 찾아서 드러내고 그것들의 법칙과 패턴 등을 밝히고자 하는 연구도 중요하고, 시대적 배경과 조건 속에서 특정한 국면과 맥락을 띠고 형성하며 변화하는 역동 성을 추적하는 연구들도 필요한 것이다.

주지하다시피, 이 연구는 '체육인' 개념이 탄생하게 된 맥 락을 살펴본 일종의 공시적 분석의 개념史 연구이다. 따라 서 '체육인' 의 개념에 어떠한 의미 변화와 지속이 있었는지 를 질문하면서, 공시적 분석의 축적과 통시적 분석의 아우 름을 함께 추진할 필요가 있다. 다시 말해, 스포츠와 관련된 다양한 개념(들)의 의미가 변화하고 지속하는 구조와 흐름 속에 관계하고 있는 다양한 역사적, 정치적, 사회적, 문화적 맥락과 언어적 담론의 지형 등을 공시적/통시적으로 접합하 여 '개념'에 대한 개념 사용의 역사를 완성해 나가는 것이다.

필자들의 두 번째 바램은 한국의 체육과 스포츠를 '역사 화' 하는 학술적 활동, 즉 '스포츠 역사하기(doing a sport history)'의 본질과 성격에 관한 것이다. 이 글의 전반부에 서 설명하였듯이, 이 연구의 목적과 성격은 역사 속을 살아 간 ‘체육인'이 과연 '누구’ 였는지를 정확하게 분간하여 가려 내기보다는, 그들이 과연 '어떠한' 사람이었을지를 이해해 보고 해석하는 작업이었다. 부족하지만, 이 작업을 마무리 하면서 강조하고 싶은 한 가지 포인트는, 필자들 역시 과거 를 살아간 '체육인'들에 대해 그들을 향한 자랑스러움, 존 경, 그리고 경외감만큼이나 부끄러움, 반성, 그리고 착잡함 도 함께 느낄 수 있었다는 점이다. 혹시 이것이 연구자의 객 관성을 저해하는 심각한 요소인지, 아니면, 다양한 사료들 의 흔적과 발자취 속에서 과거를 살아간 사람들의 일상적 생

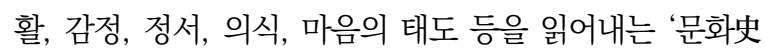
(cultural history)'와 접속할 수 있는 개념史의 유의미한 특징이 될 수 있는 것인지 솔직히 잘 모르겠다.

다만, 한 가지 명확한 것은, '한국체육史' 혹은 '한국스포 츠史'라는 이름 아래 '역사화'되어 생산, 유통되고 있는 지 식과 정보 중에는 유독, 아니 획일적이라고 할 수 있을 만큼, 과거를 살아간 사람들의 스포츠 흔적, 발자취, 행적 등을 '자 부심'과 '긍지'의 감정으로 틀 짓는 서사들만 존재한다는 것 이다. 조금 극단적인 표현일지 모르지만, 단언컨대, 우리의
체육-스포츠史를 만들고 구성하고 보존, 전승하는 학술적 실제 속에는, 비판적 문제의식으로 역사적 반성과 성찰을 추구하는 작업이 거의 없다.

우리가 살아가는 삶 속에는 자랑스러운 것도 있고 부끄러 운 것도 있기 마련이다. 오늘의 현재를 낳은 과거 속에도 자 랑스러운 것과 함께 부끄러운 것 또한 있기 마련이다. 그렇 다면, 과연 수치스럽고 부끄러운 과거들은 그 자체로 나쁜 것인가? 다시 말해, 그것들은 오늘을 사는 우리에게 아무런 (역사적) 의미가 없는 것인가? 생각해보건대, 수치스럽고 부 끄러운 과거 그 자체가 나쁘고 의미 없는 것이라기보다는, 그것들을 인지하지 못하고 성찰하지 못하는 것이 곧 역사 앞 에서 부끄럽고 수치스럽게 되는 일일 것이다. 우리의 (스포 츠) 과거 속에 존재하는 많은 수치와 부끄러움의 흔적과 자 취들이, 다양한 (스포츠) 역사학자들의 비판적이고 성찰적 인 안목과 통찰을 통해 '역사화' 되는 지식 생산의 문화가 가 까운 미래에 조성되기를 바라는 마음으로 이 글을 마친다.

\section{참고문헌}

Chosun Ilbo. (1946. 1. 9.). The idea of physical education for nation building: I. p. A2.

Chosun Ilbo. (1946. 1. 10.). The idea of physical education for nation building: II. A2.

Chosun Ilbo. (1946. 3. 5a.). Show your toughness. p. A2.

Chosun Ilbo. (1946. 3. 5b.). Physical education as a driving force for the Unification. p. A2.

Chosun Ilbo. (1946. 3. 5c.). Toward physical education for the public. A. 2

Chosun Ilbo. (1946. 3. 5d.). An expectation for the sporting leaders. p. A2.

Chosun Ilbo. (1946. 3. 5e.) Physical education is all about educational practice. p. A2.

Chosun Ilbo. (1949. 4. 13). An ongoing problem of factionalism in the Korean sporting governance. A2.

Chosun Ilbo. (1952. 5. 8). Pal-Meon-Bong(Editoiral). A1.

Chosun Ilbo. (1952. 10. 26.). Where's the spirit of the athleticism. p. A2.

Chosun Ilbo. (1954. 10. 20.). A voice for the true sportsmanship. p. A1.

Chosun Ilbo. (1955. 6. 15.). The spirit of judo. p. A4. 
Chosun Ilbo. (1959. 4. 30). Sport promotion and disputes in the Korean sporting communities. p. A2.

Chosun Ilbo. (1960. 5. 1). A power struggle for the governance in the Korean Sport Council. p. A3.

Chosun Ilbo. (1960. 5. 4). For purification of the Korean sporting communities. p. A4.

Chosun Ilbo. (1960. 9. 11). Physical educators across the country must reflect on the current problems in the Korean sporting communities. p. A2.

Chosun Ilbo. (1961. 6. 16). Enhancement for physical strength and denouncement of the politics. p. A3.

Chosun Ilbo. (1961. 9. 16). For enhancement of national prestige by producing world-class-level athletes. p. A2.

Dong-A Ilbo. (1947. 3. 22.) A joint statement by the community of patriotic organizations. p. A2.

Dong-A Ilbo. (1947. 4. 22.a). Emotional Voices touched by the victory of Mr. Seo. p. A3.

Dong-A Ilbo. (1947. 4. 22.b). Suggestions for Che-Yuk-In. p. A4.

Dong-A Ilbo. (1947. 6. 24.) A touching welcome-celebration for three heroic marathoners. p. A2.

Dong-A Ilbo. (1949. 3. 13.) Where's the donation of 140 million won for the Olympics: sport is more than just running, shooting, and hitting. p. A2.

Dong-A Ilbo. (1949. 4. 13.) Presidential address: bring minds together first! p. A2.

Dong-A Ilbo. (1949. 4. 13.) a shameful accident of bloody fight at the Kim-Po airport, an urgent need for purification of the Korean sporting organizational governance. p. A3.

Dong-A Ilbo. (1951. 1. 14.) Che-Yuk-In Registration. p. A2.

Dong-A Ilbo. (1952. 5. 13.) A sudden resignation of the president Cho from the Korean Sport Council. p. A2.

Dong-A Ilbo. (1952. 11. 10.) Factional conflicts in the Korean Sporting Communities. p. A2.

Dong-A Ilbo. (1953. 9. 9.) Conflicts in the Korean Sporting Communities. p. A2.

Dong-A Ilbo. (1956. 10. 23.) Controversy over the selection for the Olympic team. p. A2.

Dong-A Ilbo. (1956. 10. 31.) The Olympics is not the place where anybody can go and participate. p. A2.

Dong-A Ilbo. (1958. 8. 13.) Ten years of history for the Korean Sporting Communities with its inception. p. A2.
Dong-A Ilbo. (1959. 4. 11.) Solutions for the Korean Sport Council. p. A2.

Dong-A Ilbo. (1960. 9. 14.) A disastrous defeat in the Olympics and the existing personnel in the sporting communities should reflect on it. p. A1.

Hong, T. (2019). Nationalist governmentality and nation-building: birth of nation as subject of anti-communism and economic development after liberation of 1945. Culture and Politics, 6(2), 101-138

Im, C. (2012). The New Life Movement in the post-liberation days of South Korea. Critical Studies on Modern Korean History, 24(2), 219-265.

Hong, Y. P. (2011). A study on the sporting magazine of 'Physical Education Culture': a meaningful step for promoting Korean ethnic physical strength. The Modern Bibliography Review, 3, 196-204.

Jeon, G. C. (2005). Mobilization of gookmin, formation of 'gookmin': a historical study of the discourse of 'gookmin' in Korea. Korean Journal of Communication \& Information, 31, 261-293.

Jung, H., Lee, Y., Jung, J., \& Jeon, H. (2019). Basic research for the survey on the living conditions for the sports people. Seoul: KISS.

Kim, G. B. (2009). A critical understanding of identity of Korean-ness from historical perspectives of Korea, Philosophy \& Reality, 12, 56-73.

Kim, H. I. (2015). A study on Rolf Reichardt's conceptual history. In G. G. Park (Eds.), The horizon and future of conceptual history (pp. 128-175). Seoul: Sohwa.

Kim, J. (2012). National identity and the image of the West in Munmyeong and Seonjinguk Discourses during the Rhee Syngman Administration: Focusing on presidential addresses and the Chosun Ilbo. Korean Journal of Sociology, 46(2), 150-175.

Kim, M. \& Son, H. (2019). A study on the reconstruction and activities of Chosun Sport Association in the post-liberation. Asian Journal of Physical Education and Sport Science, 7(3), 95 108.

Kyunghyang Shinmun. (1946. 10. 20). Suggestions for Korean sporting communities. p. A2.

Kyunghyang Shinmun. (1947. 4. 27). The vision of the sporting nation of Korea. p. A2. 
Kyunghyang Shinmun. (1948. 8. 20). Why Korean marathoners lost at the Olympic Games. p. A2.

Kyunghyang Shinmun. (1949. 4. 16). The dark side of corruption in the Korean sporting governance. p. A2.

Kyunghyang Shinmun (1950. 5. 10). Marathon Runners as an international diplomat. p. A2.

Kyunghyang Shinmun (1952. 12. 26). A dying year of 1952: conflicts and ostentation in the Korean Sporting Communities. p. A2.

Kyunghyang Shinmun (1955. 12. 31). Suggestions for the Korean Sporting Communities in the New Year. p. A2.

Kyunghyang Shinmun (1956. 10. 17). Not for the number of people, but for the participation itself. p. A2.

Kyunghyang Shinmun. (1957. 6. 27). Che-Yuk-In and journalist. p. A3.

Kyunghyang Shinmun. (1958. 9. 5). Che-Yuk-In. p. A2.

Kyunghyang Shinmun. (1958. 10. 10). Urging for Che-Yuk-In's self-reflection. p. A1.

Kyunghyang Shinmun. (1958. 12. 10). Mystery in the Sporting Communities. p. A2.

Kyunghyang Shinmun. (1958. 12. 12). Empty Prayers. p. A2. Kyunghyang Shinmun. (1959. 4. 4). Disputes in the Korean Sports Council and solutions for them. p. A1.

Kyunghyang Shinmun. (19560. 5. 7). For shedding reliance on the administrative power. p. A4.

Kyunghyang Shinmun. (1960. 6. 22). A power vacuum in the Korean Sport Council without board composition. p. A3.

Kyunghyang Shinmun. (1960. 6. 24). A reorganization of the Korea sporting communities as the most important task. p. A2.
Kyunghyang Shinmun. (1960. 9. 11). A true turning point for reconstructing the Korean sporting governance. p. A2.

Kyunghyang Shinmun. (1961. 6. 17). Enhancement for people's physical strength and policy for the development of physical education. p. A3.

Lee, B. H. (1946, January 9). The foundatinal idea of Korean sports. Chosun Ilbo, p. A2.

$\mathrm{Na}$, I. (2003). A critical understanding of the Europeans' self-consciousness through a conceptual history approach to the concepts of 'civilization' and 'culture' (1750 1918/19), Critical Studies on Modern Korean History, 10, 11-43.

$\mathrm{Na}$, I. (2010a). A study on Kosellect's conceptual history, History for Future, 41, 271-293.

$\mathrm{Na}$, I. (2010b). About what conceptual history can do, Philosophy \& Reality, 12, 171-179.

Na, I. (2014). Concept and historical reality, Korean Education, 98, 35-57.

Na, I. (2015). Why conceptual history is new?. In G. G. Park (Eds.), The horizon and future of conceptual history (pp. 236-269). Seoul: Sohwa.

Shim, J. (2016). Song for the nation: the rightist vision of moral reform through popular music in postcolonial Korea in the Cold War era, 1945 1961. Popular Culture, 18, 100-147.

Yim, S. \& Cho, M. (2009). Ji-Am, Seo, Yun-Bok`s life and athletic activities. Journal of Sport and Leisure Studies, 38(1), 65-74. 


\title{
‘체육인' 개념의 탄생에 대한 '개념史'적 해석: '자부심/긍지'와 ‘수치/부끄러움'의 서사를 통해 '자기-재현'하는 민족-국가적 주체의 체육적 표상(1945-1961)
}

\author{
서재철 ${ }^{1}$, 정현우 ${ }^{2}$ \\ 1부경대학교 교수 \\ 2한국스포츠정책과학원 선임연구위원
}

[목적] 이 연구는 '체육인'이라는 개념이 한국 사회와 스포츠 세계 속에서 매개하고 발산해 온 사회·문화적 의미의 역사성에 주목하여, 그것이 언어 및 담론의 지형 속에서 사용, 이해, 소통되어온 특정한 맥락과 양상을 '개념사(概念史, conceptual history)'라는 역사연구의 접근을 통해 해석적으로 탐구하였다. [방법] 자료 수집 및 방법과 관련해서, 네이버 뉴스라이브러리에서 제공하는 데이터베이스에서 ‘체육인'으로 검색하여 총 338편 의 기사(1945-1961)를 수집하였다. ‘체육인’이 등장하는 1945년 이전의 기사는 단 3건에 불과하였으며, 그것 이 사용되는 맥락 역시 체육과 관련된 주체들을 단순하게 지시하는 경우라 분석 대상에 포함하지 않았다. 수집 된 자료 중 ‘체육인'의 기표가 단순히 ‘체육과 관련된 주체’ 혹은 ‘체육에 종사하는 사람' 등을 지시한 기사들을 배제하였고, 최종적으로, '체육인'의 개념이 특정한 서사 구조 속에서 의미 작용을 하는 140 편의 칼럼형 기사 들을 분석 대상으로 삼았다. [결과] 필자들의 주장은 크게 세 가지다. 첫째, 해방공간과 건국 초기 당시의 한국 사회는 국가건설의 주체로서 '국민'이라는 새로운 주체를 호명하고 있었는데, '체육인'의 개념은 그러한 주체 화의 담론이 '체육'이라는 특정한 문화적 실제 속에서 매개되어 구성, 형성된 민족-국가적 주체의 '체육적' 표 상이다. 둘째, '민족/국민'에 대한 호명이 곧 그들에게 정체성을 부여하면서 주체를 구성해내는 과정이듯이, ‘체육인'의 등장과 그것의 호명 역시 특정한 집단적 주체들이 자신들의 정체성을 특정한 내용과 방식으로 구성 하고 형성하는 자기-재현의 언어이다. 셋째, 이러한 '체육인'의 지배적 의미/이데올로기는 두 가지 대립적 감 정이 공존하는 서사적 구조와 패턴으로 강화되었다. 한편으로, '체육인'의 개념은 체육과 관련된 주체들의 빛 나는 성과와 업적을 표현, 확인하는 서사 속에 등장하면서 '자부심과 긍지(pride)'의 감정을 공유하는 과정을 통해 집합적 정체성을 정의하고 구축한다. 그리고 다른 한편으로, 그것은 체육과 관련된 주체들의 부정적이고 불미스러운 사건과 행태들을 지적하고 비판하는 서사 속에 등장하면서 '수치와 부끄러움(shame)'의 감정을 성찰하는 수사적 의식을 통해 다시금 '체육인'의 (긍정적인) 집합적 정체성을 재결속하고 재강화한다. [결론] ‘체육인'의 개념이 탄생하게 된 양상과 맥락의 내용과 성격 등을 요약함과 동시에, 아울러 한국의 역사 속에 자리하고 있는 체육과 관련된 다양한 개념과 언어에 대한 '개념사'적 탐구가 필요하다는 점, 그리고 과거 속의 체육·스포츠를 역사화하는 방식에는 비단 성공과 업적을 찬양하고 기념하는 자부심/긍지의 '(스포츠) 역사하 기' 뿐 아니라, 실패와 잘못을 되새기며 성찰하는 수치/부끄러움의 '(스포츠) 역사하기'도 필요하고 또 가치 있다는 점을 제언하였다.

주요어: 개념, 개념사, 체육인, 자부심과 수치의 정치학, 순수성 